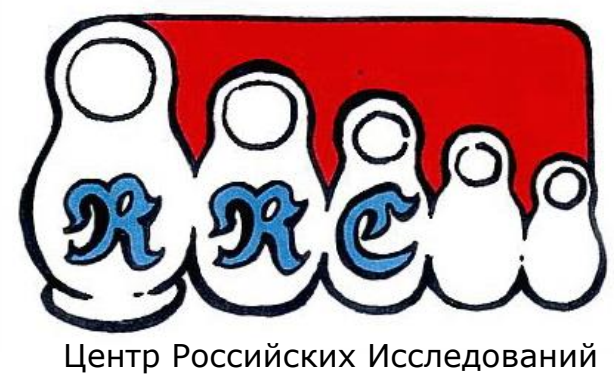
RRC Working Paper Series No. 55

Central Bank Independence and Inflation in Transition Economies: A Comparative Meta-Analysis with Developed and Developing Economies

Ichiro IWASAKI and Akira UEGAKI

\author{
RUSSIAN RESEARCH CENTER \\ THE INSTITUTE OF ECONOMIC RESEARCH \\ HITOTSUBASHI UNIVERSITY \\ Kunitachi, Tokyo, JAPAN
}


RRC Working Paper No. 55

August 2015

\title{
Central Bank Independence and Inflation in Transition Economies: A Comparative Meta-Analysis with Developed and Developing Economies
}

\author{
Ichiro Iwasaki ${ }^{\dagger}$ and Akira Uegaki ${ }^{\ddagger}$
}

\begin{abstract}
This paper aims to evaluate the central bank reforms in Central and Eastern Europe and the former Soviet countries through a comparative meta-analysis between studies of transition economies and those of other developed and developing economies that empirically examined the effect of central bank independence (CBI) on inflation. The results of a meta-synthesis using a total of 282 estimates collected from existing literature indicates that both transition and non-transition studies have successfully identified a negative relationship between CBI and inflation. Moreover, our meta-regression analysis suggested that the choice of estimator, inflation variable type, degree of freedom, and quality level of the study strongly affected the empirical results concerning transition economies. We also found that no significant difference exists between the two types of studies in terms of both effect size and statistical significance so long as we control for the degree of freedom and quality level of the study, implying that the socioeconomic setting of the society has so substantially developed in transition economies that the relation between CBI and its disinflation effect is observed in the same way as in non-transition economies.
\end{abstract}

JEL classification numbers: E31, E58, G18, P24, P34

Keywords: central bank independence, inflation, transition economies, Central and Eastern Europe, former Soviet Union, meta-analysis, publication selection bias

\footnotetext{
* This research work was financially supported by grants-in-aid for scientific research from the Ministry of Education, Culture, Sports, Science and Technology of Japan (Nos. 23243032 and 15H01849). We thank Evžen Kocenda as well as participants at the First World Congress of Comparative Economics at Roma Tre University, Rome, June 25-27, 2015, for their helpful comments and suggestions. We also would like to thank Eriko Yoshida for her research assistance and Tammy Bicket for her editorial assistance.

$\dagger$ Russian Research Center, Institute of Economic Research, Hitotsubashi University 2-1 Naka, Kunitachi, Tokyo 186-8603, Japan. E-mail: iiwasaki@ier.hit-u.ac.jp

\$ Department of Economics, Seinan Gakuin University, 6-2-92 Nishijin, Sawara-ku, Fukuoka 814-8511, Japan. E-mail: uegaki@seinan-gu.ac.jp
} 


\section{Introduction}

At the initial stage of the transformation process from a planned system to a market economy in Central and Eastern Europe (CEE) and the former Soviet Union (FSU) that began in earnest after the collapse of the Berlin Wall in 1989, policy makers and researchers, as compared to planning or finance authorities, paid little attention to banking sector reforms that played only a passive role in the socialist economic system. ${ }^{1}$ Before long, however, people who were involved in the structural reforms of the CEE and FSU countries came to realize that central bank reform and the building of a two-tier banking system is a task as important and difficult as economic liberalization and enterprise privatization. In fact, as Table 1 shows, even in 2014, at a stage where a quarter century had passed since the beginning of the economic transition, not only had the banking sector of none of these countries failed to reach a level that satisfies the standards of an industrialized market economy, but also many of the countries were still stuck in the middle or low stages of development, demonstrating that establishing a banking system appropriate for a market economy is an extremely difficult policy objective.

As a result, the bulk of research work regarding banking reforms in transition economies has been published in the last 25 years, and many of these studies have focused on the issue of central bank independence (CBI). The transition from a planned system to a market economy implies a drastic separation of politics from the economy, which, in the era of socialism, were two sides of the same coin; from this perspective, independence of the central bank from the government was regarded as an important touchstone for assessing the progress of the systemic transformation in the CEE and FSU countries. For this reason, many researchers not only tried to measure the degree of $\mathrm{CBI}$ in these countries but also carried out empirical studies that examined the relationship between CBI and inflation in response to the call from Kydland and Prescott (1977) and Barro and Gordon (1983). Since the pioneering research work of Loungani and Sheets (1997), many empirical results have been published, including the recent work of Petrevski et al. (2012).

This series of transition studies, however, has never reached a definite conclusion about the disinflation effect of CBI across the literature, probably due to significant differences in study conditions, including target countries, estimation periods, and empirical methodologies. In addition, although Cukierman et al. (2002) pointed out that "[o]n average, aggregate legal independence of new central banks in transition economies is substantially higher than CBI in

\footnotetext{
${ }^{1}$ In fact, the Washington Consensus stops short of touching on the liberalization of interest as one of its policy packages, mentioning almost nothing about banking reform (Iwasaki and Suzuki, 2016).
} 
developed economies during the 1980s" (p. 243) and provided an inkling of possible overrating of CBI in transition economies, succeeding studies have not presented any clear answer to the issue they raised.

In this paper, we will tackle these two crucial issues concerning CBI in transition economies through a meta-analysis of transition studies and comparable studies targeting other developed and developing economies. Klomp and de Haan (2010) offered a pioneering systematic review of this research area and included several works on transition economies in their meta-analysis. However, they did not provide a direct answer to the above question. In addition, due to the timing of publication, this article does not take into account a number of studies on transition economies published in the 2010s. Our paper is unique not only in that it is the first meta-study to focus on transition economies but also in that it carries out a comparative meta-analysis with other world economies.

The meta-synthesis of a total of 282 estimates collected from existing literature indicates that both transition studies and non-transition studies have successfully identified a negative relationship between CBI and inflation. Moreover, our meta-regression analysis (MRA) of the heterogeneity among relevant studies suggested that the choice of estimator, inflation variable type, degree of freedom, and quality level of the study strongly affected the empirical results regarding transition economies. We also provide evidence that no significant difference exists between the two types of studies in terms of both effect size and statistical significance, so long as we control for the degree of freedom and the quality level of the study. This result implies that the socioeconomic setting of a society concerning the CBI-inflation problem has as substantially developed in transition economies as in other developed and developing economies. However, we found that, although transition studies include genuine empirical evidence of the disinflation effect of CBI in their estimates, non-transition studies have prevented us from identifying a true effect, perhaps due to the strong influence of publication selection bias.

The remainder of this paper is organized as follows: Section 2 provides an overall picture of central bank reforms in transition economies. Section 3 theoretically considers the relationship between $\mathrm{CBI}$ and inflation and reviews recent empirical studies of transition economies. Section 4 discusses the procedure of the literature search, an outline of the collected estimates, and the meta-analysis methodology. Section 5 conducts a comparative meta-analysis between transition studies and non-transition studies, including assessment of publication selection bias. Section 6 summarizes the major findings and concludes the paper. 


\section{Central Bank Reforms in Transition Economies}

In this section, we describe the value, progress, and diversity of central bank reforms in CEE and FSU countries. To this end, in Subsection 2.1, we argue the significance of establishing a two-tier banking system and central bank reform in the former socialist countries, and in Subsection 2.2, we discuss the process of banking reforms and the promotion of CBI and indicate the reform divergence among transition economies.

\subsection{Establishment of a Two-Tier Banking System and Central Bank Reform in Transition Economies}

In a socialist planned economy, banking is characterized by a one-tier banking system. In the socialist economies, the central bank concurrently carried out both the function of a central bank and that of a commercial bank. In other words, under the socialist system, the central bank not only was an issue bank but also provided short-term working capital for state enterprises. However, such a monopoly of the central bank does not necessarily mean that the bank plays a leading role in the national economy. Instead, the important point is that, as money had only a passive role in the planned system, the central bank therefore had no means of implementing monetary policies that would actually impact economic activities. In fact, central banks in socialist states have never engaged in any traditional operations of central banks, such as open market operations and the discounting of commercial bills (Gregory and Stuart, 1986; Lavigne, 1999).

Accordingly, from the viewpoint of a banking system, transitioning from a planned economy to a market economy means demolishing such a mono-bank system to create a two-tier system comprised of the central bank as the first tier and commercial banks as the second tier. In many cases, the building of a two-tier banking system was formally carried out at a very early stage of transition, in some countries, even before the collapse of the socialist regime. As a matter of fact, the transition of the Soviet mono-banking system to a two-tier structure occurred in April 1989, when commercial banks were first allowed to operate, and a legal reserve system was introduced (Kokorev and Remizov, 1996). On the other hand, two-tier banking systems were constituted in Hungary, Poland, and Czechoslovakia in 1987, 1989, and 1990, respectively (Barisitz, 2008). Of these, the banking reform in Hungary was particularly advanced. As early as December 1984, the Central Committee of the Hungarian Socialist Workers' Party declared that "the central banking and commercial banking functions have to be separated within the National Bank of Hungary and preparations for the establishment of a two-tier banking system have to begin" (MPD of NBH, 2000, p. 15); on January 1, 1987, a two-tier banking system actually started to operate (Varhegyi, 1994). In 
Bulgaria, a two-tier banking system was also built from 1987 to 1989, and in Romania in 1990; almost at the same time, the establishment of private banks was also permitted (Barisitz, 2008).

Along with the establishment of a two-tier banking system, money started to play a more positive role in the economic system; hence, central banks also started to function in new roles. Actually, they began to influence the behaviors of enterprises, commercial banks, households, and the government in an indirect manner through the manipulation of interest rates, the money supply, and the exchange rate. However, this indirect manner did not mean that the influence of the central bank was weak because, in a society where the market economy is fully functioning, a small change in the interest rate, the amount of money in circulation, or the exchange rate could have a significant impact on the whole national economy.

In this way, the central banks of the CEE and FSU countries that used to be subordinate to the activities of other economic entities during the socialist era came to gain indirect but strong power of influence as the transition to a market economy progressed. This process and the independence of the central banks were inseparably bound to each other. Namely, the basic scenario of central bank reform in the former socialist countries was to give the central bank the ability to make independent policy decisions and enable it to carry out monetary policies, even those not necessarily welcomed by the government and/or citizens. Therefore, from a financial perspective, the degree of $\mathrm{CBI}$ can be regarded as an important barometer of the systemic transformation.

The important point here is that various European Union (EU) agreements contain provisions concerning the independence of the European Central Bank (ECB) and central banks in member states. For instance, the treaty on the functioning of the EU has the following provision:

When exercising the powers and carrying out the tasks and duties conferred upon them by the Treaties and the Statute of the ESCB and of the ECB, neither the European Central Bank, nor a national central bank, nor any member of their decision-making bodies shall seek or take instructions from Union institutions, bodies, offices or agencies, from any government of a Member State or from any other body (Article 130). ${ }^{2}$

This meant that the government of a CEE country that intends to join the EU must have a strong awareness that the reinforcement of CBI is one of their primary policy objectives. With such a mandate, how did the CEE and FSU countries try to secure and promote the independence of their central banks?

\footnotetext{
${ }^{2}$ From the Foundation for EU Democracy (2008, p. 103)
} 


\subsection{Banking Reform Progress and the Independence of Central Banks}

As discussed above, central bank reform in transition economies can be viewed as a process of ensuring and strengthening CBI underpinned by the establishment of a two-tier system. However, to answer the question as to under what financial system the policy objectives of the government, including stabilization of the macro-economy and acceleration of economic growth, can be achieved, we should also pay attention to banking reforms in general. In other words, although encompassing central bank reforms, much wider reforms are also important, including the liberalization of interest rates, abolition of directed credit or interest rate ceilings, establishment of bank solvency and of a framework for prudential supervision and regulation, increased presence of private banks in the financial market and their increased lending to private enterprises, well-functioning banking competition, and substantial financial deepening. ${ }^{3}$

In principle, banking reforms and reinforcement of CBI should keep pace with each other. When we look back on the history of transition economies, however, these two did not necessarily proceeded hand-in-hand. In Figure 1, the vertical axis takes the index for banking reform and interest rate liberalization provided by the European Bank for Reconstruction and Development (EBRD). It is a five-grade index ranging from 1 to $4+$ and covers almost all CEE and FSU countries. ${ }^{4}$ The horizontal axis shows the degree of CBI based on the LVAW index developed by Cukierman et al. (1992) and Cukierman (1992) and on the GMT index proposed by Grillini et al. (1991). The former is an index for evaluating CBI from the perspective of the legal system; it gives an average score of 16 investigated items weighted by their relative importance. The latter is a point total determined by assessing 8 legal and 7 economic items and adding a value of 1 for each item that falls under that category.

Panels (a) and (b) of Figure 1 show, respectively, a scatter plot of the EBRD banking reform index and the LVAW index in the middle of the 1990s and that of the EBRD index and the GMT index in the early 2000s. As the approximate line drawn in each graph suggests, there is a positive correlation between banking reform progress and the degree of $\mathrm{CBI}$ in the CEE and FSU countries. At the same time, Figure 1 also indicates a significant divergence of the reform paths among these countries not only in the mid-1990s but even in the early 2000s.

It is easy to understand why Estonia, which continued its reforms all the way to the

\footnotetext{
3 These are reform items on which the EBRD's index for banking reform and interest rate liberalization is based.

4 See the EBRD website (http://www.ebrd.com/what-we-do/economic-research-and-data/data. $\mathrm{html}$ ) for more details regarding the index. The EBRD stopped publishing this index in 2010; since 2011, it has been replaced by a sector-level transition indicator, which is used in Table 1.
} 
introduction of the Euro, is ranked high with respect to both indices, while Russia, which faced weak political influence from the EU, is ranked low in both indices in Figure 1. On the other hand, the positions of Hungary and Georgia are worthy of mention. In Hungary, although general progress in banking reform was the highest among the CEE and FSU countries both in the mid-1990s and early 2000s, its CBI was lower than that in other reforming countries. In Hungary, at the initial stage of transition, policies for strengthening CBI progressed rapidly along with banking reforms, notwithstanding adverse political circumstances. ${ }^{5}$ As a background for this, there was a national goal to join the EU, which the Hungarian people earnestly wanted. However, once it was decided that Hungary would become a new member of the EU, a certain move to undermine CBI was witnessed (Meagher, 2003; Civelekoğlu, 2013). As shown in Figure 1, Slovenia and Slovakia also showed a tendency similar to that of Hungary in the mid-1990s. In addition to these two countries, in the early 2000s, Bulgaria also took up a parallel position. These facts suggest that central bank reforms in some CEE countries were implemented hand-in-hand with the policy objective of becoming a member of the EU (NBS, 2011; Ahtik et al., 2012; Iskrov, 2009).

With respect to Georgia, although the banking reform progress is ranked low, CBI is evaluated as high as in the Central European countries. Armenia in both periods, Moldova and Belarus in the 1990s, and Kyrgyzstan and Tajikistan in the 2000s showed similar tendencies. Both the LVAW index and the GMT index are designed to assess the level of CBI from an institutional standard perspective. Georgia and the other five FSU countries are small countries where legislative capability is not necessarily adequate. Therefore, they tend to imitate advanced legal systems in a faithful manner upon receiving policy recommendations and/or technical assistance from western countries and international organizations. We conjecture that this has resulted in a remarkably high level of pro forma CBI, as compared with the banking reform progress in these countries.

In sum, the overall pattern of banking reforms and CBI in the CEE and FSU region is nothing but diversity. On one hand, there is a country such as Estonia, where both of these two policy elements are highly developed; on the other hand, there are countries such as Russia, where both elements have been at a low level. There are also notable exceptions, such as Hungary and Georgia. While the question of why such diversity has occurred would be an important research topic from the perspective of historical path-dependence, that is not where our interest lies. Rather, we would like to examine in this paper the relationship between CBI

5 These adverse circumstances include issues related to non-performing loans of former state-owned banks, debts of former state-owned enterprises, capital injection to loss-making commercial banks, and twin deficits of the national budget and current accounts. 
and inflation. For policy makers in CEE and FSU countries, addressing the inflation risk was the most challenging and urgent task in the area of financial policy.

\section{Central Bank Independence and Inflation: Literature Review}

As Table 2 shows, the dynamics of inflation in transition economies had two faces. First, all former socialist countries experienced extremely high inflation with the transformation of the economic system. However, there was significant diversity from country to country in terms of how inflation proceeded: First, peak inflation rates varied widely, as did the years in which inflation peaked. Second, some countries were still showing high inflation rates of around $10 \%$ year-on-year, even in the 2000s when inflation was moving toward resolution in the entire region.

With respect to why high inflation occurred in all CEE and FSU countries without exception, Rautava (1993) pointed to the serious shortage economy under socialism as well as monetary overhang, which means excessive accumulation of currency in the hands of citizens and other economic entities. On the other hand, the diversity of inflation dynamics was caused by country-to-country differences in the nature of price liberalization, the scale of subsidiary funded by the issuing of currency to state-owned enterprises, the monopolistic industrial organization under the planned system, and the foreign exchange policies of the central banks.

Because of our interest in this paper, we cast a spotlight on the diversity observed in the inflation trends. We argue that more fundamental factors should exist behind such diversity, as was observed in the process of price level fluctuation in the transition economies. That is exactly the aspect where central banks are sacrificing their own mission to stabilize the currency value for the sake of other policy objectives under pressure from the government and business circles. This introduces the issue of the relationship between CBI and inflation.

On this issue, there has been an accumulation of studies, both theoretical and empirical. From the theoretical point of view, Kydland and Prescott (1977) and Barro and Gordon (1983), who argued that discretionary financial policies create a so-called "time (or dynamic) inconsistency problem," made notable contributions (Romer, 1996). Of the policy tools developed to deal with this problem, the one particularly relevant to our research interest is a "delegation" strategy advocated by Rogoff (1985), who proposed to delegate financial policies to a body that has a different idea from the general public; i.e., a person who strongly dislikes inflation. In other words, his argument implies that there exists a negative correlation between $\mathrm{CBI}$ and inflation.

In response to the above theoretical arguments, Alesina (1988), Grillini et al. (1991), 
Cukierman et al. (1992), and Alesina and Summers (1993) developed unique CBI indices and empirically examined the relationship between inflation and CBI in developed and developing economies. ${ }^{6}$ Following these pioneering works, studies on former socialist transition economies also started appearing in 1997. They include: Loungani and Sheets (1997), Maliszewski (2000), Cukierman et al. (2002), Eijffinger and Stadhouders (2003), Hammermann and Flanagan (2007), Dumiter (2011), Maslowska (2011), Bogoev et al. (2012a), Bogoev et al. (2012b), and Petrevski et al. (2012). Hereinafter, we will especially review studies after Dumiter (2011), which are not covered by Klomp and de Haan (2010).

Dumiter (2011) developed his own comprehensive CBI index and examined the correlation between this original index and macroeconomic indicators, including inflation. While examining not only the data of transition economies but also those of other developed and developing economies, he obtained evidence that, in any country, the higher the degree of CBI, the more the economy moves toward such a stable path as to achieve improved macroeconomic performance, so long as a middle-to-high degree of CBI has been achieved, and an inflation target has been imposed.

As Dumiter (2011) did, Maslowska (2011) also covered not only transition economies but also other economies in the world. The aim of this paper is unique because by comparing various scales of $\mathrm{CBI}$, she tried to examine which is most appropriate in order to empirically verify a negative correlation between $\mathrm{CBI}$ and inflation rates. Thus, this paper provides valuable empirical data for examining the heterogeneity among different studies by meta-analysis.

Bogoev et al. (2012a, 2012b) and Petrevski et al. (2012) are a heterochromatic group of empirical studies because they came to different conclusions regarding the disinflation effect of CBI, despite having been published in the same year by the same group of researchers and having dealt with the same subject. In fact, while Bogoev et al. (2012a) reported that "CBI is found to have a statistically significant and economically important negative effect on inflation" (p. 93), Bogoev et al. (2012b) stated that " $[\mathrm{t}]$ he role of CBI as a disinflation device in transition economies may have been overstated" (p. 54). Furthermore, Petrevski et al. (2012) concluded that "[t]he results from our empirical models do not provide empirical support for the significant and negative relationship between CBI and inflation in transition economies" ( $p$. 646). We conjecture that the presence of the remarkably different research outcomes is closely related to the differences in study conditions among these papers, including the empirical model, the estimation period, and the target countries. Hence, we will give consideration to

\footnotetext{
${ }^{6}$ Arnone et al. (2006) provide an excellent review of empirical studies in this research field.
} 
these factors in the meta-analysis conducted in this paper.

In addition to the studies published in the 2010 s, we would like to make particular reference to Cukierman et al. (2002) because they provided a very important consideration from the perspective of meta-analysis of the transition literature: the legal independence of central banks in transition economies was much higher than that in developed economies observed in the 1980s. Hereafter, we call their finding the "Cukierman proposition." This fact was pointed out in a preceding study (Wagner, 1999) and has been reemphasized in relatively recent studies as well (Bouyon, 2009; Bogoev et al., 2012b). If there has been a tendency to overemphasize $\mathrm{CBI}$ in transition economies that was measured by legal standard, it is possible that, in the transition study, it might become difficult to empirically verify the hypothesis that the higher the CBI, the higher its negative impact on inflation.

What can we deduce from the review of the transition literature mentioned above? First, the empirical results of transition economies regarding the disinflation effect of CBI as a whole are mixed; hence, it is difficult to grasp the whole picture through a narrative review of the previous studies. Second, although Dumiter (2011) and Maslowska (2011) conducted an empirical analysis using data of developed and developing economies to compare with transition economies, these papers do not necessarily work out the differences between the two. This is also true for Eijffinger and Stadhouders (2003). ${ }^{7}$ Third, every author is concerned with how to measure CBI or what kind of proxy should be utilized to capture the impact of CBI on inflation. Particularly, one's conclusion would be different depending on how one assesses the Cukierman proposition that hints at a possible overestimate of $\mathrm{CBI}$ in transition economies as compared with developed economies in the 1980s. From our viewpoint, this means that we must assess whether there is a significant difference in empirical results regarding the CBI disinflation effect between a legal-based index and other kinds of indicators used in the previous studies.

On the basis of the above discussions, the task of our meta-analysis becomes clear: we should shed light on the characteristics of transition economies as compared to other developed and developing economies while explicitly incorporating into our meta-analysis the differences in $\mathrm{CBI}$ indices, paying special attention to the Cukierman proposition. To deal with this task, in the following two sections, we will conduct a comparative meta-analysis between transition

\footnotetext{
${ }^{7}$ Eijffinger and Stadhouders (2003) studied 44 developed and developing economies and 18 transition economies and, based on their estimation results, concluded that, with regard to transition economies, "[d]uring early phases of liberalization legal CBI is unrelated to inflation. But when sufficient high levels of liberalization are reached, and holding other things the same, legal CBI and inflation are significantly and negatively related" (p. 29).
} 
and non-transition studies.

\section{Procedure of Literature Search, Outline of Collected Estimates, and Meta-Analysis Methodology}

In this section, as the first step in achieving the task mentioned above, we will discuss our procedure for searching and selecting studies regarding the disinflation effect of CBI and outline the collected estimates as well as the meta-analysis methodology employed in this study.

To identify relevant studies that empirically examined the effect of CBI on inflation in the CEE and FSU countries as well as those concerning other developed and developing countries that could be targeted for comparison with transition studies, we first searched EconLit, Web of Science, and Google Scholar databases for research works that had been registered in the 25 years from 1989 to $2014 .^{8}$ Here, we carried out an AND search using "central bank," "independence," and "inflation" as keywords. As a result, we identified more than 800 references; from these, we obtained 125 papers that actually conducted empirical examinations of the impact of CBI on inflation. After that, we closely examined the content of these 125 works and narrowed the literature list to those containing estimates that could be subjected to meta-analysis for this paper.

Consequently, as Table 3 reports, for transition studies, we selected 10 papers from Loungani and Sheets (1997) to Petrevski et al. (2012), referenced in the preceding section; for non-transition studies, we chose 12 works from Walsh (1997) to Alpanda and Honig (2014). We selected the latter according to the following three criteria: (1) countries targeted for the study do not include the CEE and FSU countries at all or, if including them, use only data whose ratio in the observation is negligible; (2) the study was published in or after 1997, the year Loungani and Sheets' paper appeared; (3) with respect to the estimation period, the study reports empirical results after 1980. By fulfilling the above conditions, these non-transition studies become comparable to the transition studies in terms of publication timing and the period targeted for study. Furthermore, as mentioned in the preceding section, Eijffinger and Stadhouders (2003), Dumiter (2011), and Maslowska (2011) reported not only estimates for the CEE and FSU countries but for other countries of the world. Therefore, as Table 3 shows, we included these three studies in both literature categories.

The total number of country observations in the ten transition studies listed in Panel (a) of Table 3 is 202, of which CEE EU countries account for 48.5\% (98 observations); other CEE

\footnotetext{
${ }^{8}$ The final literature search using these databases was conducted in January 2015.
} 
countries, 14.9\% (30 observations); and FSU countries, excluding the Baltic States, 33.7\% (68 observations). In addition, four studies also used observations of Mongolia and other emerging economies, although they account for only a very small percentage.

We collected a total of 109 estimates from the transition studies (10.9 per study on average). Their estimation period covers 22 years, from 1989 to 2010. The average estimation period is 11.7 years (median: 9 years). While 8 out of 10 studies used panel data, studies that utilized cross-sectional data total only 3 . The CBI variables employed by the transition studies can be categorized into 6 types: comprehensive index has the largest share and accounts for 54 or $49.5 \%$ in total estimates of transition economies. Legal index follows with 47 estimates ( $43.1 \%$ in total), while the numbers of estimates of governor term, political index, economic index, and governor turnover count only 3,2,2, and 1, respectively.

With respect to the non-transition studies listed in Panel (b) of Table 3, their total number of country observations reaches 422, in which the share of developed and developing economies account for $19.9 \%$ (84 observations) and $80.1 \%$ (338 observations), respectively. From these twelve papers, we collected a total of 173 estimates (14.4 per study on average). The estimation period of these 173 estimates ranges within 29 years from 1980 to 2008, with an average estimation period of 14.8 years (median: 13 years). Seven of 12 works performed panel data analysis, while 5 papers conducted cross-sectional analysis. The breakdown of collected estimates of non-transition economies by CBI variable type is as follows: governor turnover accounts for 49.7\% (86 estimates); followed by legal index, 31.2\% (54); comprehensive index, 9.8\% (17); political index, 5.2\% (9); and economic index, 4.0\% (7). There is no estimate of governor term. As reported above, a notable characteristic of the non-transition studies is the frequent use of governor turnover in contrast to the transition studies.

Because we adopt estimates of governor turnover, whose theoretically expected sign is positive (i.e., the higher the governor turnover, the lower the $\mathrm{CBI}$ ), and those of other indices, for which it is negative (i.e., the higher the value of the index, the higher the CBI), all together for our meta-analysis, we carried out coding by reversing the sign of the coefficient and the $t$ value in the case of estimates of governor turnover. Note that the meta-analysis and interpretation of its results in this paper will be conducted under this condition.

Next, we outline the meta-analysis to be conducted in the following sections. In this study, we employ the partial correlation coefficient (PCC) and the $t$ value to synthesize the collected estimates. The PCC is a measure of association of a dependent variable and the independent variable in question when other variables are held constant. The PCC is calculated in the following equation: 


$$
r_{k}=\frac{t_{k}}{\sqrt{t_{k}^{2}+d f_{k}}}, \quad k=1,2, \ldots, K,(1)
$$

where $t_{k}$ and $d f_{k}$ denote the $t$ value and the degree of freedom of the $k$-th estimate, respectively, while $K$ denotes the total number of collected estimates. We synthesize PCCs by the meta fixed-effect model and the meta random-effects model and, according to the homogeneity test, we adopt the synthesized effect size of one of these two models as the reference value.

Following Djankov and Murrell (2002), we combine $t$ values using the next equation:

$$
\overline{T_{w}}=\sum_{k=1}^{K} w_{k} t_{k} / \sqrt{\sum_{k=1}^{K} w_{k}^{2}} \sim N(0,1) .
$$

Here, $w_{k}$ is the weight assigned to the $t$ value of the $k$-th estimate. As the weight $w_{k}$ in Eq. (2), we utilize a 10-point scale to mirror the quality level of each relevant study $(1 \leq$ $\left.w_{k} \leq 10\right) .{ }^{9}$ Moreover, we report not only the combined $t$ value $\overline{T_{w}}$ weighted by the quality level of the study, but also the unweighted combined $t$ value $\overline{T_{u}}$. As a supplemental statistic for evaluating the reliability of the above-mentioned combined $t$ value, we also report Rosenthal's fail-safe $\mathrm{N}\left(f_{S} N\right)$.

Following the synthesis of collected estimates, we conduct MRA to explore the factors causing heterogeneity between selected studies. To this end, we estimate the meta-regression model:

$$
y_{k}=\beta_{0}+\sum_{n=1}^{N} \beta_{n} x_{k n}+e_{k}, k=1,2, \cdots, K,
$$

where $y_{k}$ is the PCC or the $t$ value of the $k$-th estimate; $x_{k n}$ denotes a meta-independent variable that captures relevant characteristics of an empirical study and explains its systematic variation from other empirical results in the literature; $\beta_{n}$ denotes the meta-regression coefficient to be estimated; and $e_{k}$ is the meta-regression disturbance term (Stanley and Jarrell, 2005). To check the statistical robustness of coefficient $\beta_{n}$, we perform an MRA using the following six estimators: the cluster-robust ordinary least squares (OLS) estimator, which clusters the collected estimates by study and computes robust standard errors; the cluster-robust weighted least squares (WLS) estimator, which uses either the above-mentioned quality level of the study, the number of observations, or the inverse of the standard error $(1 / S E)$ as an analytical weight; the multilevel mixed effects restricted maximum likelihood (RML) estimator; and the unbalanced panel estimator (i.e., fixed-effects estimator and random-effects estimator).

\footnotetext{
${ }^{9}$ For more details on the method of evaluating the quality level of the study, see Appendix.
} 
Testing for publication selection bias is an important issue. In this paper, we examine this problem by using the funnel plot and the Galbraith plot as well as by estimating the meta-regression model that is designed especially for this purpose. If the funnel plot is not bilaterally symmetrical but is deflected to one side, then an arbitrary manipulation of the study area in question is suspected, in the sense that estimates in favor of a specific conclusion (i.e., estimates with an expected sign) are more frequently published (type I publication selection bias). Meanwhile, the Galbraith plot is used for testing another arbitrary manipulation in the sense that estimates with higher statistical significance are more frequently published, irrespective of their sign (type II publication selection bias). In general, the statistic, $\mid$ (the $k$ - th estimate - the true effect) $/ S E_{k} \mid$, should not exceed the critical value of \pm 1.96 by more than $5 \%$ of the total estimates. In other words, when the true effect does not exist and there is no publication selection, the reported $t$ values should vary randomly around zero, and $95 \%$ of them should be within the range of \pm 1.96 . The Galbraith plot tests whether the above relationship can be observed in the statistical significance of the collected estimates, and thereby identifies the presence of type II publication selection bias.

In addition to the above two scatter plots, we also report estimates of the meta-regression models, which have been developed to examine in a more rigorous manner the two types of publication selection bias and the presence of the true effect.

We can test for type I publication selection bias by regressing the $t$ value of the $k$-th estimate on the inverse of the standard error (1/SE) using the following equation:

$$
t_{k}=\beta_{0}+\beta_{1}\left(1 / S E_{k}\right)+v_{k}
$$

and thereby testing the null hypothesis that the intercept term $\beta_{0}$ is equal to zero. In Eq. (4), $v_{k}$ is the error term. When the intercept term $\beta_{0}$ is statistically significantly different from zero, we can interpret that the distribution of the effect sizes is asymmetric. For this reason, this test is called the funnel-asymmetry test (FAT). Meanwhile, type II publication selection bias can be tested by estimating the next equation, where the left side of Eq. (4) is replaced with the absolute $t$ value:

$$
\left|t_{k}\right|=\beta_{0}+\beta_{1}\left(1 / S E_{k}\right)+v_{k}
$$

thereby testing the null hypothesis of $\beta_{0}=0$ in the same way as the FAT.

Even if there is a publication selection bias, a genuine effect may exist in the available empirical evidence. Stanley and Doucouliagos (2012) propose examining this possibility by testing the null hypothesis that the coefficient $\beta_{1}$ is equal to zero in Eq. (4). The rejection of the null hypothesis implies the presence of a genuine effect. They call this test the precision-effect test (PET). Moreover, they also state that an estimate of the publication-selection-bias-adjusted 
effect size can be obtained by estimating the following equation that has no intercept:

$$
t_{k}=\beta_{0} S E_{k}+\beta_{1}\left(1 / S E_{k}\right)+v_{k},
$$

thereby obtaining the coefficient $\beta_{1}$. This means that if the null hypothesis of $\beta_{1}=0$ is rejected, then the non-zero effect does actually exist in the literature, and that the coefficient $\beta_{1}$ can be regarded as its estimate. Stanley and Doucouliagos (2012) call this procedure the precision-effect estimate with standard error (PEESE) approach. To test the robustness of the regression coefficient, we estimate Eq. (4) to (6) above using not only the OLS estimator, but also the cluster-robust OLS estimator and the unbalanced panel estimator, ${ }^{10}$ both of which treat possible heterogeneity among the studies.

As mentioned above, we basically follow the FAT-PET-PEESE approach advocated by Stanley and Doucouliagos (2012) as the test procedures for publication selection. However, we also include the test of type II publication selection bias using Eq. (5), because, as Iwasaki and Tokunaga (2014) stressed, this kind of bias is very likely in the literature of transition economies.

\section{Meta-Analysis}

In this section, we will conduct a comparison of the transition and non-transition studies listed in Table 3 by meta-analysis using a total of 282 collected estimates, following the procedure described in the previous section. More specifically, in Subsection 5.1, we will synthesize the collected estimates. In Subsection 5.2, MRA of heterogeneity among studies will be performed. Then, in Subsection 5.3, we will test the publication selection bias and the presence of genuine empirical evidence in each study field.

\subsection{Synthesis of the Collected Estimates}

Table 4 shows descriptive statistics of PCC and $t$ values of collected estimates, and Figure 2 shows their frequency distribution. As shown in Panels (a) of Table 4 and Figure 2, PCCs of the transition studies show a skewed distribution toward the negative direction with the mode of 0.0. According to Cohen's (1988) criteria, $45.9 \%$ (50 estimates) do not show any practical relationship between CBI and inflation in the transition economies $(|r|<1.0)$, while 11.9\% (13 estimates) report a small disinflation effect of CBI (1.0 $\leq|r| \leq 3.0)$; the remaining $42.2 \%$ (46

\footnotetext{
${ }^{10}$ To estimate Eqs. (4) and (5), we use either the random-effects estimator or the fixed-effects estimator according to the results of the Hausman test of the random-effects assumption. With regard to Eq. (6), which does not have an intercept term, we report the random-effects model estimated by the maximum likelihood method.
} 
estimates) indicate a medium or large effect $(3.0<|r|)$. Since 68 of 109 estimates take a negative PCC, empirical results that support the presence of a disinflation effect of CBI in transition economies account for $62.4 \%$ of the total collected estimates.

With respect to the PCC of non-transition studies, although its distribution range is almost the same as in the case of the transition studies, the bias toward the negative direction is obviously stronger than that of the transition studies. In fact, the mode of the non-transition studies is -0.2 ; moreover, 138 PCCs, or $79.8 \%$ of their estimates, are negative. As a result, the number of estimates that indicate a practical effect of CBI on inflation $(1.0 \leq|r|)$ reaches 151 $(87.2 \%)$ of 173 , which greatly exceeds that of the transition studies.

According to Panels (b) of Table 4 and Figure 2, although the mode of the $t$ values of the estimates obtained from the transition studies is 0.5 , they show not only a long skewed distribution toward the negative direction, but also estimates of -2.0 or under account for $35.8 \%$ (39 estimates) of the total. On the other hand, with respect to the $t$ values of the estimates collected from the non-transition studies, not only is the mode -3.0 , but also 104 $(60.1 \%)$ out of 173 estimates have a $t$ value equal to or less than -2.0. Judging from the distribution of PCCs and $t$ values, it can be said that those studies that target developed and developing economies have detected a negative impact of CBI on inflation that is larger in effect size and more statistically significant than in those studies that investigated transition economies.

The above evaluation is also supported by the results of meta-synthesis. Column (a) of Table 5 reports the synthesized PCCs. If we adopt the synthesized effect size $\overline{R_{r}}$ of the random-effects model as the reference value in accordance with the homogeneity test, the synthesized effect size of the non-transition studies using all collected estimates surpasses that of the transition studies in terms of its absolute value; the former is -0.152 , while the latter is -0.114 . Hence, the absolute value of the former is 0.038 larger than the latter. In other words, as compared to the transition studies, the non-transition studies report an approximately $33.3 \%$ greater effect size as a whole of literature. In addition, as Column (b) of Table 5 shows, not only in terms of unconditionally combined $t$ value $\overline{T_{u}}$ but also in terms of the combined $t$ value $\overline{T_{w}}$ weighted by the quality level of the study, the non-transition studies exceed the transition studies by a large margin. The same applies for Rosenthal's fail-safe N. In this regard, however, we note that, common to both study areas, the value of $\overline{T_{w}}$ is substantially lower than $\overline{T_{u}}$, suggesting that there may exist a strong negative correlation between the statistical significance of the estimates and the research quality, irrespective of the target region.

Further, we also conducted meta-synthesis of estimates collected from the transition studies, focusing on differences in target countries, estimation periods, data types, and CBI 
variable types. Based on these results reported in Table 5, we confirmed that: first, with respect to those studies for which the estimation period includes the 2000s and those that used panel data, the effect size became far smaller than those studies for which the estimation period was limited to the 1990s or those that used cross-sectional data; second, not only did differences in CBI variable types result in a large difference in terms of the synthesized effect size, ranging from -0.798 (governor turnover) to -0.060 (legal index), but also the estimates that used the economic index could not reject the null hypothesis; and third, although the unconditionally combined $t$ value $\overline{T_{u}}$ is significant and negative in all 12 cases, the combined $t$ value $\overline{T_{w}}$ weighted by the quality level of the study dropped below the $10 \%$ significance level in seven cases.

The above results from the meta-synthesis of collected estimates strongly suggest that the empirical results of the transition studies concerning the disinflation effect of CBI are inferior to those of comparable studies in terms of both effect size and statistical significance. From this result, we can argue that, if independence from the government and other economic entities is at the same level, the price control of the central banks in the CEE and FSU countries is weaker than that of their counterparts in the rest of the world. At the same time, however, it is possible to interpret that, since $\mathrm{CBI}$ variables used in the transition studies have greater measurement errors than those employed in the non-transition studies, researchers of transition economies were not able to capture the disinflation effect of CBI as effectively as were those who studied other developed and developing economies.

As shown in Table 5, the fact that those studies of transition economies that used the legal index reported unsatisfactory empirical results, particularly in terms of effect size, as compared to those that used other indices, indicates the possibility of the overestimation of CBI in the CEE and FSU countries alluded to in the Cukierman proposition mentioned in Section 3. However, the meta-synthesis in this section has a serious problem, in that it does not give consideration to the differences in study conditions between previous works. Therefore, in the next subsection, we will conduct an MRA to examine whether the results of meta-synthesis can be reproduced while simultaneously controlling for a series of study conditions.

\subsection{Meta-Regression Analysis of Heterogeneity among Studies}

In this subsection, we will estimate the regression equation defined in Eq. (3) to identify factors that may cause heterogeneity among studies of transition economies and between transition and non-transition studies. As explained in Section 4, we will estimate a meta-regression model that takes the PCC or $t$ value as a dependent variable. As meta-independent variables, we will control for the estimator used, the inflation variable type, 
the lagged structure of the CBI variable, and the degree of freedom ${ }^{11}$ as well as the quality level of the study, in addition to the composition of target countries, the estimation period, the data type, and the CBI variable type that are mentioned in the previous subsection. Table 6 lists the name, definition, and descriptive statistics of these meta-independent variables.

Table 7 shows the estimation results concerning heterogeneity among studies of transition economies. With regard to unbalanced panel regression models [6] and [12], the null hypothesis is not rejected by the Hausman test in both cases; hence, we report the random-effects models. In addition, the Breusch-Pagan test accepts the null hypothesis that the variance of the individual effects is zero. Therefore, estimates of the restricted maximum likelihood estimation and the random-effects method are rarely different from those of the OLS model. On the other hand, although the WLS models are sensitive to the choice of analytical weights, many variables are uniformly estimated, with statistical significance at the 10\% level or less. In other words, the estimates in Table 7 are robust beyond the difference estimator.

On the basis of meta-independent variables that are statistically significant and have the same sign (positive or negative) in more than four of six models, we indicate the following six points in relation to the factors that cause significant differences in empirical results among studies of transition economies. First, the composition of target countries has a significant impact on the statistical significance of their estimates. As shown in Panel (b) of Table 7, those empirical studies that employ more observation of the CEE non-EU member countries and/or the FSU countries than of the CEE EU countries have detected a more statistically significant negative impact of CBI on inflation. As Table 2 indicates, as compared with the CEE EU countries, other former socialist states, particularly the FSU countries, suffered a sharp rise in prices in the early stage of transition; however, they have since experienced a quick end to this. During this period, the central bank reforms in these non-EU member countries made considerable progress, although not to the extent of the CEE EU countries. It is likely that this historical fact resulted in the detection of a statistically stronger correlation between the marginal increase of $\mathrm{CBI}$ and inflation in the non-EU transitional countries than in the CEE EU member states.

Second, the estimation period also has an impact on the statistical significance of the estimates. In other words, the closer the first year of the estimation period is to the present and the longer the length of estimation, the lower the statistical significance of the negative impact

${ }^{11}$ Sample size has a considerable influence on the statistical significance of estimates. Therefore, many meta-studies, from a statistics perspective, use the square root of the degree of freedom as a control variable for the meta-regression model. 
of CBI on inflation tends to be. The decline of the relative weight of the data regarding the hyperinflation observed in the early 1990s is considered to be closely related to this result.

Third, in contrast to the results of meta-synthesis reported in Table 5, if other study conditions are equal, those studies that employed panel data tend to obtain supporting evidence of the disinflation effect of CBI, both in terms of the effect size and the statistical significance. Compared to cross-sectional data, the use of panel data may work favorably for examining the relationship between price fluctuations and CBI, by virtue of its greater amount of information. Meanwhile, a similar interpretation can apply to those studies that used the OLS estimator; however, it seems that the main reason for this result is the use of other estimators that take into account country-level fixed effects, heterogeneity of variance, and the endogeneity of dependent and independent variables tends to more strictly assess the effect of CBI.

Fourth, studies that used transformed inflation variables, as compared to those that used price variables without any transformation, tend to more conservatively assess the impact of $\mathrm{CBI}$ on inflation. The transformation of variables to smooth the price fluctuation might have a mitigation effect on the empirical evaluation of the correlation between the steep increase of prices observed in the early stage of transition and a low level of CBI.

Fifth, while compared to those studies that used the comprehensive index as a CBI variable, those that used the governor turnover tend to obtain estimates that emphasize the negative impact of CBI on inflation more strongly, not only in terms of the effect size but also in terms of the statistical significance. ${ }^{12}$ It is also noteworthy that there is no statistically significant difference between those studies that employed political, economic, or legal indices and those that used a comprehensive index. As argued in Section 2, it is possible that the presence of heterodox countries such as Hungary or Georgia, where the promotion of institutional independence of the central bank and banking reform progress were not necessarily closely linked, could provide background for the weaker explanatory power of these pro forma indices than of governor turnover. Furthermore, the result that the meta-independent variable that captures the use of a lagged CBI variable is estimated to be significant and negative in Panel (b) of Table 7 indicates the importance of taking into account the time lag effect of CBI for examining its correlation with inflation.

Sixth, there is a clear tendency that the better the quality level of a study, the stricter the

12 On the other hand, surprisingly, those studies that measured CBI by governor term tend more conservatively assess the CBI disinflation effect. We surmise that this might happen because the governor term is cut off at the upper limit of the legal term for the sake of data, although the governor of a central bank, in fact, could have served a number of terms or resigned in the middle of the term. 
empirical evaluation of the disinflation effect of $\mathrm{CBI}$ in transition economies. This result is consistent with the findings mentioned in the previous subsection.

In sum, the estimation results of Table 7 strongly suggest that a series of differences in study conditions and research quality have resulted in significant differences in the empirical results reported in studies concerning transition economies.

Next, we will analyze the relative robustness of the disinflation effect of CBI in transition economies as compared with other developed and developing economies with the goal of evaluating the substance of the central bank reforms in the CEE and FSU countries in relation to the Cukierman proposition discussed above. To this end, using all estimates collected both from the transition and non-transition studies, we regressed the PCC and $t$ value on a dummy variable that specifies the estimates collected from the transition studies by a value of 1 , controlling the degree of freedom and the quality level of the study.

Table 8 shows the result. Although the dummy for the transition studies shows a positive sign both for the PCC and $t$ value, it is not significant in ten of twelve models. In other words, if the degree of freedom and the study quality are held constant, no statistically significant differences are found between the empirical results reported by the transition studies and those by the non-transition studies. Although we do not report the estimation results here, even if we added other meta-independent variables into the right-hand side of the regression equation to control for other study conditions, the dummy for transition studies has never been significantly estimated. ${ }^{13}$ In addition, even when we limited observations to estimates of the legal CBI index, it also did not show robust estimates. ${ }^{14}$ These results imply that, in terms of the degree of linkage between CBI and inflation, there is not much difference between the transition economies and the rest of the world. The concern with the central bank reforms in the CEE and FSU countries from the viewpoint of the disinflation effect of CBI, triggered by the argument in Cukierman et al. (2002) (namely, the Cukierman proposition), is probably unfounded, if the policy developments in the 2000s are taken into consideration. In this sense, we can assess that the policy efforts in the former socialist countries actually led to substantial results. $^{15}$

13 This is consistent with the estimation result that a dummy variable for estimates of transition economies is not significant in the meta-regression model of Klomp and de Haan (2010), which takes the $t$ value as a dependent variable (Table 4, p. 606).

${ }^{14}$ More precisely, the dummy for the transition studies was insignificant in four of six models that take the PCC as a dependent variable and in all six models using the $t$ value.

${ }^{15}$ Cukierman et al. (2002) argue that it is "too extreme" to conclude that the difference in the degree of legal independence of the central banks in the transition economies does not have much influence on inflation just because the legal index of central bank independence of transition 


\subsection{Assessment of Publication Selection Bias}

Last, we will examine the publication selection bias and the presence of genuine empirical evidence, following the methodology described in Section 4.

Figure 3 is a funnel plot using PCCs and the respective inverse of the standard errors. Panel (a) of this figure illustrates the plot for the transition studies. Here, we do not find a bilaterally symmetric and inverted funnel-shaped distribution of the collected estimates in both cases when either zero or the mean value of the top $10 \%$ most-precise estimates $(-0.310)$ is used as an approximate value of the true effect. ${ }^{16}$ If the true effect exists around zero, then the ratio of the positive versus the negative estimates becomes $41: 68$, which rejects the null hypothesis that the ratio is $50: 50$ at the $1 \%$ significance level $(z=-2.586, p=0.009)$; therefore, type I publication selection bias is suspected. If the true effect is assumed to be close to the mean of the top $10 \%$ most-precise estimates, the distribution of collected estimates is greatly skewed to the right, as they are divided into a ratio of $27: 82$, with a value of -0.310 being the threshold; therefore, the null hypothesis is strongly rejected under this assumption as well $(z=5.268, p=0.000)$. Accordingly, the possibility of type I publication selection bias is considered to be very high among studies of transition economies.

With regard to non-transition studies, the ratio of the positive versus the negative estimates becomes 35:138, and the ratio of the left and right with the mean value of the top $10 \%$ most-precise estimates of -0.184 being the threshold is $80: 93$; therefore, if the true effect exists around zero, the possibility of the presence of type I publication selection bias is very high $(z=-7.830, p=0.000)$; however, if the true value is assumed to be the mean of the top $10 \%$ most-precise estimates, the possibility of the presence of type I publication selection bias is considered to be low $(z=0.988, p=0.323$ ). This is represented by the funnel plot in Panel (b) of Figure 3, although not in a clear-cut manner, showing a bilaterally symmetric and triangle-shaped distribution, with a value of -0.184 being the threshold.

Figure 4 shows a Galbraith plot using $t$ values and the respective inverse of the standard errors. This figure strongly indicates the presence of type II publication selection bias in both study areas. In fact, among the collected estimates of the transition studies, only 72 of the 109 estimates show a $t$ value that is within the range of \pm 1.96 or two-sided critical values at the $5 \%$ significance level; therefore, the null hypothesis that the rate as a percentage of total collected estimations is $95 \%$ is rejected $(z=-13.866, p=0.000)$. With respect to the non-transition studies,

economies does not reflect the true degree of independence (p. 255).

${ }^{16}$ The method for assuming the mean of the top $10 \%$ most-precise estimates is the approximate value of the true effect is along the lines of Stanley (2005). 
only 80 of 173 estimates also show a $t$ value that is within the range of \pm 1.96 ; therefore, the null hypothesis that the rate as a percentage of total collected estimations is $95 \%$ is also strongly rejected $(z=-29.425, p=0.000)$. Furthermore, even on the assumption that the mean of the top $10 \%$ most-precise estimates stands for the true effect, the corresponding result also rejects the null hypothesis that estimates in which the statistic I(the $k$ th estimate the true effect) $/ S E_{k} \mid$ exceeds the critical value of 1.96 account for $5 \%$ of all estimates in both study areas. ${ }^{17}$ Accordingly, we affirm that it is highly likely that type II publication selection bias arises in this research field, regardless of target regions.

Table 9 reports the estimation results of the meta-regression models that are specially designed to examine publication selection bias and the presence of genuine empirical evidence of the disinflation effect of CBI. According to the estimation results of Models [1] to [3], contrary to the findings from the funnel plot mentioned above, the funnel asymmetry test (FAT) accepts the null hypothesis that the intercept term $\beta_{0}$ is zero in all three models and, accordingly, does not prove the presence of type I publication selection bias in transition studies. On the contrary, in Models [4] to [6], the null hypothesis is rejected in all three models at the $1 \%$ significance level; therefore, type I publication selection bias is strongly suspected in non-transition studies. Meanwhile, Panel (b) of the same table shows that the null hypothesis is rejected at the $1 \%$ or $5 \%$ significance level in all six models. Thus, the likelihood of type II publication selection bias is significantly high in both study areas.

Now, we return to Panel (a) of Table 9 and look at the results of a precision-effect test (PET). The test results of the transition studies reject the null hypothesis that the coefficient of the inverse of the standard error $\beta_{1}$ is zero in all three models, implying that the collected estimates from the transition studies may include genuine evidence concerning the effect of CBI on inflation. In contrast, with regard to non-transition studies, the null hypothesis is accepted in two of three models. Accordingly, it is less likely that there is genuine empirical evidence in the estimates used in this paper. In Panel (c) of Table 9, the precision-effect estimate with standard error (PEESE) rejects the null hypothesis that the coefficient of the inverse of the standard error $\beta_{1}$ is zero in all six models, suggesting that the true effect of CBI on inflation is significantly negative irrespective of the study area. However, in respect to the non-transition studies, the publication-bias-adjusted effect size obtained from PEESE cannot be adopted since the PET cannot reject the null hypothesis as mentioned above.

Judging from these results, we conclude that the estimates collected from the non-transition studies do not provide genuine empirical evidence, perhaps due to the strong

${ }^{17}$ The $z$-value and the $p$-value of the test for equality of proportions are -34.521 and 0.000 for transition studies and -46.518 and 0.000 for non-transition studies, respectively. 
influence of publication selection biases. Accordingly, the results of the comparative meta-analysis reported in this section should be interpreted with a certain degree of reservation.

\section{Conclusions}

It has been a quarter century since the collapse of the Communist bloc. During these 25 years, CEE and FSU countries have employed and implemented various structural reforms to establish market economies. Central bank reform is one of the important policy measures to be carried out by these countries, and, hence, researchers have been paying a great deal of attention to every movement in this policy area. The large numbers of studies that have been published so far give testimony to this strong interest.

As discussed in Section 2, central bank reforms have progressed to a certain extent in all transition economies since the collapse of the Berlin Wall to the present. However, reflecting significant differences in policy principles for the transformation to a market-oriented system and other domestic circumstances, the progress of reform differs considerably from country to country. At the same time, price stabilization was an urgent policy concern for every government in the CEE and FSU countries. Although there were several reasons for high inflation and the diversity of price dynamics observed in these economies, in this paper, we cast a spotlight on the relationship between CBI and inflation. While a number of empirical studies that focused on this relationship with developed and developing economies as their targets have been published since the early 1990 s, researchers of transition economies have also produced a certain number of empirical studies on this issue. By conducting a comparative meta-analysis using the estimates collected from previous studies, we examined whether the disinflation effect of CBI has been actually detected in the transition literature as a whole and whether the empirical results of transition economies are comparable to those of non-transition economies, keeping the Cukierman proposition in mind.

From the results of the meta-analysis using a total of 282 estimates collected from 10 studies of transition economies and 12 non-transition studies, we came up with the following findings:

First, the synthesized PCC and the combined $t$ value of the collected estimates are negative and statistically significant in both study areas, suggesting that, irrespective of the target region, the negative impact of CBI on inflation is verified in the literature as a whole. However, it was also revealed that the effect size and the statistical significance of the transition studies are inferior to those of non-transition studies. 
Second, the meta-synthesis of the estimates collected from the transition studies indicated the possibility that their empirical results are strongly affected by a series of study conditions, including the target country, the estimation period, the data type, and the type of index used to measure CBI.

Third, the MRA also reproduced the close correlation between various study conditions and the estimates reported in the transition studies. More specifically, the heterogeneity among studies of transition economies is caused by the choice of estimator, inflation variable type, degree of freedom, and research quality, in particular.

Fourth, the MRA using the collected estimates of both transition and non-transition studies revealed that there is no statistically significant difference between the two types of studies so long as we control for the degree of freedom and the quality level of the study. It is worth mentioning that we obtained similar results even when we utilized only the estimates of the legal CBI index.

Fifth, according to the results of the assessment of publication selection bias, we found that, while the transition studies contain genuine empirical evidence of the disinflation effect of CBI in their estimates beyond type II publication selection bias, the non-transition studies failed to provide evidence of a non-zero effect of $\mathrm{CBI}$, due to the strong influence of publication selection bias on their empirical results.

With respect to the relationship between the process of central bank reform in the CEE and FSU countries discussed in Section 2 and the results of our meta-analysis, we can point out the following:

First, not only the contrast between Russia, where the reforms of both the central bank and the banking system are slow and, accordingly, the level of CBI is low, and Estonia, where central bank reform has progressed considerably and the degree of CBI is remarkably high, but also the positive correlation between the progress of banking reforms and CBI, shown in Figure 1, is consistent with the results from our meta-analysis; the negative impact of CBI on inflation in the transition economies is comparable with that in other countries, suggesting that close correlations between central bank reform, reinforcement of $\mathrm{CBI}$, and price dynamics have emerged in CEE and FSU countries, as observed in other developed and developing countries.

Second, it is likely that the existence of a group of countries such as Hungary and Georgia, which deviate considerably from the normal reform process, produced the meta-synthesis results that the effect size and the statistical significance reported by the transition studies as a whole are inferior to those of the non-transition studies; such a situation is the root of the issue raised by Cukierman et al. (2002). This is due to a situation among the transition economies 
where, while inflation was effectively controlled even in those countries that had outwardly low levels of CBI, such as Hungary, it was not controlled as effectively as it could have been in countries that appeared to have a high level of CBI, such as Georgia. However, the fact that the MRA does not support the results of meta-synthesis, in which study conditions are not controlled for simultaneously, indicates that the influence of these unorthodox countries on the empirical results is not as significant as we had predicted. Therefore, we conclude that the concern arising from the Cukierman proposition is unfounded, in consideration of the development of central bank reform in the 2000s as well.

To summarize, the results of our meta-analysis strongly back up the argument that the socioeconomic progress is substantial, in the sense that there exists a close relationship between CBI and inflation in the post-communist world. However, the results never support the contention that the central banks in the CEE and FSU countries have reached a desirable level of independence from policy makers and other parties with interests in monetary policies. Rather, in many of transition economies, the central bank is still under the strong control of political leaders and the central government. Accordingly, we should pay careful attention to further development of this aspect. 


\section{APPENDIX METHOD FOR EVALUATING THE QUALITY LEVEL OF A STUDY}

This appendix describes the evaluation method used to determine the quality level of the studies subjected to our meta-analysis.

For journal articles, we used the ranking of economics journals that had been published as of November 1, 2012, by IDEAS - the largest bibliographic database dedicated to economics and available freely on the Internet (http://ideas.repec.org/) - as the most basic information source for our evaluation of quality level. IDEAS provides the world's most comprehensive ranking of economics journals, and as of November 2012, 1173 academic journals were ranked.

We divided these 1173 journals into 10 clusters using a cluster analysis based on overall evaluation scores, and assigned each of these journal clusters a score (weight) from 1 (the lowest journal cluster) to 10 (the highest).

For academic journals that are not ranked by IDEAS, we referred to the Thomson Reuters Impact Factor and other journal rankings and identified the same level of IDEAS ranking-listed journals that correspond to these non-listed journals; we have assigned each of them the same score as its counterparts.

Meanwhile, for academic books and book chapters, we have assigned a score of 1 in principle, but if at least one of the following conditions is met, each of the relevant books or chapters has uniformly received a score of 4 , which is the median value of the scores assigned to the above-mentioned IDEAS ranking-listed economics journals: (1) The academic book or book chapter clearly states that it has gone through the peer review process; (2) its publisher is a leading academic publisher that has external evaluations carried out by experts; or (3) the research level of the study has been evaluated by the authors to be obviously high. 


\section{References}

Ahtik, Meta, Zrinka Erent Sunko, and Ozren Pilipovic (2012), Legal aspects of central banking in Slovenia and Croatia from their beginnings up to membership in the Euro zone, CYELP, 8:21, pp. 561-580.

Alesina, Alberto (1988), Macroeconomics and politics, NBER Macroeconomics Annual, 3, pp. 13-52.

Alesina, Alberto and Lawrence Summers (1993), Central bank independence and macroeconomic performance: some comparative evidence, Journal of Money, Credit, and Banking, 25:2, pp. 151-162.

Alpanda, Sami and Adam Honig (2014), The impact of central bank independence on the performance of inflation targeting regimes, Journal of International Money and Finance, 44, pp. 118-135.

Arnone, Marco, Bernard J. Laurens and Jean-Francois Segalotto (2006), The measurement of central bank autonomy: survey of models, indicators, and empirical evidence, Working Paper No. 06/227, International Monetary Fund (IMF): Washington, D.C.

Barisitz, Stephan (2008), Banking in Central and Eastern Europe 1980-2006, Routledge: London and New York.

Barro, Robert J. and David B. Gordon (1983), Rules, discretion and reputation in a model of monetary policy, Journal of Monetary Economics, 12:1, pp. 101-121.

Bogoev, Jane, Goran Petrevski and Bruno S. Sergi (2012a), Investigating the link between central bank independence and inflation in Central and Eastern Europe, Eastern European Economics, 50:4, pp. 78-96.

Bogoev, Jane, Goran Petrevski and Bruno S. Sergi (2012b), Reducing inflation in ex-communist economies independent central banks versus financial sector development, Problems of Post-Communism, 59:4, pp. 38-55.

Bouyon, Sylvain (2009), Currency substitution and central bank independence in the Central and Eastern European economies, Journal of Economic Integration, 24:4, pp. 597-633.

Civelekoğlu, İlke (2013), It takes two to tango: the role of the European Union and domestic governments in the making of central bank reform in Hungary, International Relations/Uluslararasi Iliskiler, 9:36, pp. 129-148.

Cohen, Jacob (1988), Statistical power analysis in the behavioral sciences, 2nd edition, Lawrence Erlbaum Associates: Hillsdale.

Cukierman, Alex (1992), Central bank strategy, credibility, and independence: theory and evidence, MIT Press: Cambridge, MA and London.

Cukierman, Alex, Geoffrey P. Miller and Bilin Neyapti (2002), Central bank reform, liberalization and inflation in transition economies: an international perspective, Journal of Monetary Economics, 49:2, pp. 237-264.

Cukierman, Alex, Steven B. Webb and Bilin Neyapti (1992), Measuring the independence of central banks and its effect on policy outcomes, World Bank Economic Review, 6:3, 353-398.

de Haan, Jakob and Willem J. Kooi (2000), Does central bank independence really matter? new evidence for developing countries using a new indicator, Journal of Banking and Finance, 24:4, pp. 643-664.

Djankov, Simeon and Peter Murrell (2002), Enterprise restructuring in transition: a quantitative survey, Journal of Economic Literature, 40:3, pp. 739-792.

Dumiter, Florin Cornel (2011), Estimating the impact of central bank independence upon 
macroeconomic performance using a panel data model, Romanian Journal of Economic Forecasting, 2011:4, pp. 106-128.

EBRD (European Bank for Reconstruction and Development), Transition report, EBRD: London. (various issues)

EBRD (2014), Transition report 2014: innovation in transition, EBRD: London.

Eijffinger, Sylvester C. W. and Patrick Stadhouders (2003), Monetary policy and the rule of law, Discussion Paper No. 3698, Centre for Economic Policy Research (CEPR): London.

Foundation for EU Democracy (2008), Consolidated reader-friendly edition of the treaty on European Union (TEU) and the treaty on the functioning of the European Union (TFEU) as amended by the treaty of Lisbon (2007). (available at: http://www.eudemocrats.org)

Gregory, Paul R. and Robert Stuart (1986), Soviet economic structure and performance, 3rd edition, Harper and Row: New York.

Grillini, Vittorio, Danato Masciandaro and Guido Tabellini (1991), Political and monetary institutions and public financial policies in the industrial countries, Economic Policy, 6:13, pp. 342-392.

Gutiérrez, Eva (2004), Inflation performance and constitutional central bank independence: evidence from Latin America and the Caribbean, Economía Mexicana - NUEVA ÉPOCA, 13:2, pp. 255-287.

Hammermann, Felix and Mark Flanagan (2007), What explains persistent inflation differentials across transition economies? Working Paper No. 07/189, International Monetary Fund (IMF): Washington, D.C.

Iskrov, Ivan (2009), Bulgarian National Bank - independence, predictability and transparency, Speech by Mr. Ivan Iskrov, Governor of the Bulgarian National Bank, before the 41st National Assembly of the Republic of Bulgaria on the occasion of his election to a second term of office, Sofia, 26 August 2009, BIS Review, 104/2009, pp. 1-2.

Iwasaki, Ichiro and Taku Suzuki (2016), Radicalism versus gradualism: an analytical survey of the transition strategy debate, Journal of Economic Surveys. (In press)

Iwasaki, Ichiro and Masahiro Tokunaga (2014), Macroeconomic impacts of FDI in transition economies: a meta-analysis, World Development, 61, pp. 53-69.

Jácome, Luis I. and Francisco Vázquez (2005), Any link between legal central bank independence and inflation? evidence from Latin America and the Caribbean, Working Paper No. 05/75, International Monetary Fund (IMF): Washington, D. C.

Jácome, Luis I. and Francisco Vázquez (2008), Is there any link between legal central bank independence and inflation? evidence from Latin America and the Caribbean, European Journal of Political Economy, 24:4, pp. 788-801.

Klomp, Jeroen and Jakob de Haan (2010), Inflation and central bank independence: a meta-regression analysis, Journal of Economic Surveys, 24:4, pp. 593-621.

Kokorev, V. and A. Remizov (1996), Modernization of Russia's credit system under conditions of a liquidity crisis: is it possible to devalue money without a rise of Inflation? Problems of Economic Transition, 39:8, pp. 41-65.

Krause, Stefan and Fabio Méndez (2008), Institutions, arrangements and preferences for inflation stability: evidence and lessons from a panel data analysis, Journal of Macroeconomics, 30:1, pp. 282-307.

Kydland, Finn E. and Edward C. Prescott (1977), Rules rather than discretion: the inconsistency of optimal plans, Journal of Political Economy, 85:3, pp. 473-492.

Lavigne, Marie (1999), The economics of transition from socialist economy to market economy, 
Macmillan: New York.

Loungani, Prakashl and Nathan Sheets (1997), Central bank independence, inflation, and growth in transition economies, Journal of Money, Credit, and Banking, 29:3, pp. 381-399.

MPD of NBH (Monetary Policy Department of the National Bank of Hungary) (2000), Monetary policy in Hungary (edited by Ilona Bozo), National Bank of Hungary: Budapest.

Maliszewski, Wociech S. (2000), Central bank independence in transition economies, Economics of Transition, 8:3, pp. 749-789.

Maslowska, Aleksandra A. (2011), Quest for the best: how to measure central bank independence and show its relationship with inflation, AUCO Czech Economic Review, 5:2, pp. 132-161.

Meagher, Patrick (2003), Changing hands: governance and transformation in Hungary's financial sector, Review of Central and East European Law, 28:1, pp. 1-76.

NBS (National Bank of Slovakia) (2011), The National Bank of Slovakia: its tasks and activities, Bratislava.

Perera, Anli, Deborah Ralston and Jayasinghe Wickramanayake (2013), Central bank financial strength and inflation: is there a robust link? Journal of Financial Stability, 9:3, pp. 399-414.

Petrevski, Goran, Jane Bogoev and Bruno S. Sergi (2012), The link between central bank independence and inflation in Central and Eastern Europe: are the results sensitive to endogeneity issue omitted dynamics and subjectivity bias? Journal of Post Keynesian Economics, 34:4, pp. 611-652.

Rautava, Jouko (1993), Monetary overhang, inflation and stabilization in the economies in transition, Review of Economies in Transition, No. 4, Bank of Finland, Institute for Economies in Transition (BOFIT): Helsinki.

Rogoff, Kenneth (1985), The optimal degree of commitment to an intermediate monetary target, Quarterly Journal of Economics, 100:4, pp. 1169-1189.

Romer, David (1996), Advanced macroeconomics, McGraw-Hill: Columbus, OH.

Stanley, T. D. (2005), Beyond publication bias, Journal of Economic Surveys, 19:3, pp. 309-345.

Stanley, T. D. and Hristos Doucouliagos (2012), Meta-regression analysis in economics and business, Routledge: London and New York.

Stanley, T. D. and Stephen B. Jarrell (2005), Meta-regression analysis: a quantitative method of literature surveys, Journal of Economic Surveys, 19:3, pp. 299-308.

Sturm, Jan-Egbert and Jakob de Haan (2001), Inflation in developing countries: does central bank independence matter? new evidence based on a new data set, Working Paper No. 511, CESifo: Munich.

Varhegyi, Eva (1994), The 'second' reform of the Hungarian banking system, In: Bonin, John P. and Istvan P. Szekely (eds.), The development and reform of financial systems in Central and Eastern Europe, Edward Elgar: Aldershot, pp. 293-308.

Wagner, Helmut (1999), Central bank independence and the lessons for transition economies from industrial countries and developing countries, Comparative Economic Studies, 41:4, pp. 1-22.

Walsh, Carl E. (1997), Inflation and central bank independence: is Japan really an outlier? Monetary and Economic Studies, 15:1, pp. 89-117. 
Table 1. Development of the banking sector in transition economies in 2014

\begin{tabular}{|c|c|}
\hline Countries ${ }^{\mathrm{a}}$ & $\begin{array}{c}\text { EBRD banking } \\
\text { sector transition } \\
\text { indicator }^{\text {b }}\end{array}$ \\
\hline Estonia & 4- \\
\hline Slovak Republic & 4- \\
\hline Poland & 4- \\
\hline Croatia & $3+$ \\
\hline Latvia & $3+$ \\
\hline Lithuania & $3+$ \\
\hline Slovenia & 3 \\
\hline Hungary & 3 \\
\hline Bulgaria & 3 \\
\hline Romania & 3 \\
\hline Albania & 3- \\
\hline Ukraine & 3- \\
\hline Georgia & $3-$ \\
\hline Serbia & $3-$ \\
\hline Bosnia and Herzegovina & $3-$ \\
\hline FYR Macedonia & 3- \\
\hline Montenegro & $3-$ \\
\hline Russia & 3- \\
\hline Armenia & $2+$ \\
\hline Kazakhstan & $2+$ \\
\hline Kosovo & $2+$ \\
\hline Moldova & $2+$ \\
\hline Azerbaijan & 2 \\
\hline Kyrgyz Republic & 2 \\
\hline Tajikistan & 2 \\
\hline Belarus & 2 \\
\hline Uzbekistan & 1 \\
\hline Turkmenistan & 1 \\
\hline \multicolumn{2}{|c|}{ Notes: } \\
\hline $\begin{array}{l}\text { a The Czech Republic is not } \\
\mathrm{b} \text { The indicator ranges fro } \\
\text { little or no change relative } \\
\text { economy and 4+ represen } \\
\text { industrialized market ecol } \\
\text { Source: EBRD, Transition R } \\
\text { Transition, EBRD: London }\end{array}$ & $\begin{array}{l}\text { th } 1 \text { representing } \\
\text { ntrally planned } \\
\text { lards of an } \\
\text { novation in }\end{array}$ \\
\hline
\end{tabular}


Figure 1. Relationship between banking reforms and central bank independence in transition economies

(a) Mid 1990s

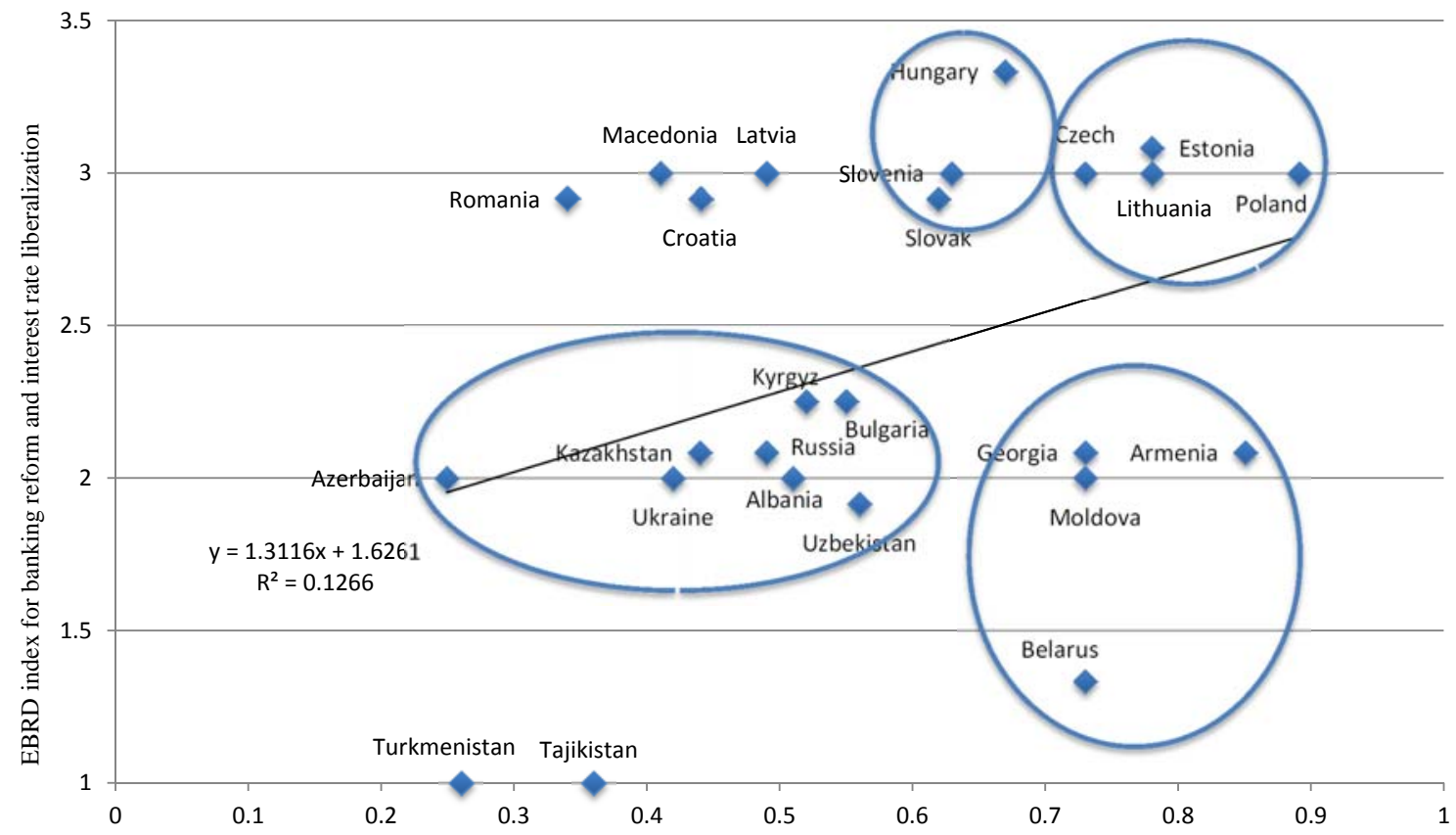

LVAW index for central bank independence

(b) First half of 2000s

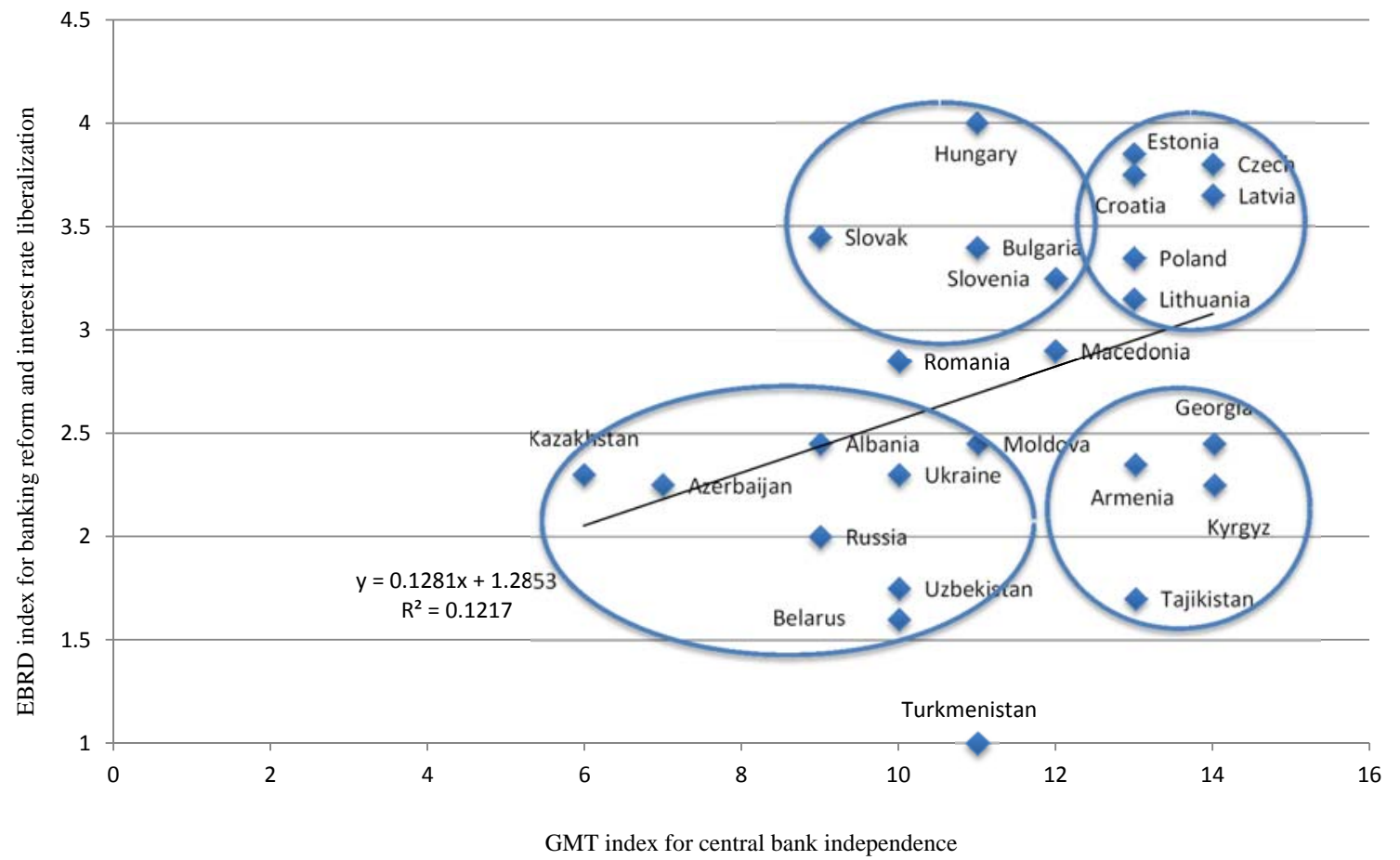

Note: The EBRD index in Panels (a) and (b) denotes the means for the periods of 1995-1997 and 2001-2005, respectively. The LVAW index in Panel (a) is the evaluation reported in Cukierman et al. (2002) that refers to laws related to the central bank, which were effective around 1996, while the GMT index in Panel (b) is the evaluation reported in Bogoev et al. (2012b), which was effective around 2003.

Source: Authors' illustration based on the EBRD, Transition Report (various issues), Cukierman et al. (2002), and Bogoev et al. (2012b). 
Table 2. Consumer price dynamics in transition economies from 1989-2010

(Annual average: \%)

\begin{tabular}{|c|c|c|c|c|c|c|c|c|c|c|c|c|c|c|c|c|c|c|c|c|c|c|}
\hline & 1989 & 1990 & 1991 & 1992 & 1993 & 1994 & 1995 & 1996 & 1997 & 1998 & 1999 & 2000 & 2001 & 2002 & 2003 & 2004 & 2005 & 2006 & 2007 & 2008 & 2009 & 2010 \\
\hline \multicolumn{23}{|l|}{ (a) CEE EU countries } \\
\hline Bulgaria & 6.4 & 26.3 & 333.5 & 82.0 & 73.0 & 96.3 & 62.0 & 123.0 & 1082.0 & 22.2 & 0.7 & 9.9 & 7.4 & 5.9 & 2.3 & 6.1 & 5.0 & 7.3 & 8.4 & 12.3 & 2.8 & 1.9 \\
\hline Croatia & & 609.5 & 123.0 & 665.5 & 1517.5 & 97.6 & 2.0 & 3.5 & 3.6 & 5.7 & 4.0 & 4.6 & 3.8 & 1.7 & 1.8 & 2.1 & 3.3 & 3.2 & 2.9 & 6.1 & 2.4 & 0.9 \\
\hline Czech Republic & 1.4 & 9.7 & 52.0 & 11.1 & 20.8 & 9.9 & 9.6 & 8.9 & 8.4 & 10.6 & 2.1 & 4.0 & 4.7 & 1.8 & 0.2 & 2.8 & 1.9 & 2.6 & 3.0 & 6.3 & 7.3 & 1.0 \\
\hline Estonia & 6.1 & 23.1 & 210.5 & 1076.0 & 89.8 & 47.7 & 29.0 & 23.1 & 11.2 & 8.1 & 3.3 & 4.0 & 5.8 & 3.6 & 1.3 & 3.0 & 4.1 & 4.4 & 6.6 & 10.4 & -0.1 & 2.8 \\
\hline Hungary & 17.0 & 28.9 & 35.0 & 23.0 & 22.5 & 18.8 & 28.2 & 23.6 & 18.3 & 14.3 & 10.0 & 9.8 & 9.2 & 5.3 & 4.7 & 6.8 & 3.6 & 3.9 & 8.0 & 6.1 & 4.2 & 4.5 \\
\hline Latvia & 4.7 & 10.5 & 172.2 & 951.2 & 109.2 & 35.9 & 35.9 & 25.0 & 17.6 & 8.4 & 4.7 & 2.6 & 2.5 & 1.9 & 2.9 & 6.2 & 6.7 & 6.5 & 10.1 & 15.4 & 3.5 & -2.5 \\
\hline Lithuania & 2.1 & 8.4 & 224.7 & 1020.5 & 410.4 & 72.1 & 39.6 & 24.6 & 8.9 & 5.1 & 0.8 & 1.0 & 1.5 & 0.3 & -1.1 & 1.2 & 2.7 & 3.8 & 5.7 & 11.0 & 4.2 & 1.0 \\
\hline Poland & 251.1 & 585.8 & 70.3 & 43.0 & 35.3 & 32.2 & 27.8 & 19.9 & 14.9 & 11.8 & 7.3 & 10.1 & 5.5 & 1.9 & 0.8 & 3.5 & 2.2 & 1.2 & 2.4 & 4.3 & 3.8 & 2.4 \\
\hline Romania & 1.1 & 5.1 & 170.2 & 210.4 & 256.1 & 136.7 & 32.3 & 38.8 & 154.8 & 59.1 & 45.8 & 45.7 & 34.5 & 22.5 & 15.3 & 11.9 & 9.1 & 6.6 & 4.9 & 7.9 & 5.6 & 6.1 \\
\hline Slovak Republic & 2.3 & 10.8 & 61.2 & 10.0 & 23.2 & 13.4 & 9.9 & 5.8 & 6.1 & 6.7 & 10.6 & 12.0 & 7.3 & 3.0 & 8.5 & 7.5 & 2.5 & 4.5 & 2.8 & 4.6 & 1.6 & 1.5 \\
\hline Slovenia & 1285.3 & 551.6 & 115.0 & 207.3 & 32.9 & 21.0 & 13.5 & 9.9 & 8.4 & 8.0 & 6.2 & 8.9 & 8.4 & 7.5 & 5.6 & 3.6 & 2.5 & 2.5 & 3.6 & 5.7 & 0.9 & 1.8 \\
\hline \multicolumn{23}{|c|}{ (b) Other CEE countries } \\
\hline Albania & 0.0 & 0.0 & 35.5 & 226.0 & 85.0 & 22.6 & 7.8 & 12.7 & 33.2 & 20.6 & 0.4 & 0.1 & 3.1 & 5.2 & 2.3 & 2.9 & 2.4 & 2.4 & 2.9 & 1.1 & 3.4 & 3.5 \\
\hline Montenegro & & & & & & & 97.0 & 80.2 & 23.4 & 32.4 & 67.6 & 97.1 & 22.6 & 16.0 & 6.7 & 2.4 & 2.3 & 3.0 & 4.2 & 8.3 & 3.4 & 1.4 \\
\hline Serbia & & & & & & 3.3 & 78.6 & 94.3 & 18.3 & 30.0 & 41.1 & 70.0 & 91.8 & 19.5 & 11.7 & 10.1 & 16.5 & 12.7 & 6.5 & 12.4 & 8.1 & 5.7 \\
\hline \multicolumn{23}{|l|}{ (c) FSU countries } \\
\hline Armenia & 4.8 & 10.3 & 274.0 & 1346.0 & 1822.0 & 4962.0 & 175.8 & 18.7 & 14.0 & 8.7 & 0.7 & -0.8 & 3.1 & 1.1 & 4.7 & 7.0 & 0.6 & 2.9 & 4.4 & 9.0 & 3.4 & 8.5 \\
\hline Azerbaijan & & 7.8 & 107.0 & 912.0 & 1129.0 & 1664.0 & 412.0 & 19.7 & 3.5 & -0.8 & -8.5 & 1.8 & 1.5 & 2.8 & 2.2 & 6.7 & 9.6 & 8.3 & 16.7 & 20.8 & 1.5 & 5.0 \\
\hline Belarus & 1.7 & 4.7 & 94.1 & 970.3 & 1190.2 & 2221.0 & 709.3 & 52.7 & 63.9 & 72.9 & 293.7 & 168.6 & 61.1 & 42.5 & 28.4 & 18.1 & 10.3 & 7.0 & 8.4 & 14.9 & 12.8 & 7.1 \\
\hline Georgia & & 3.3 & 79.0 & 887.4 & 3125.4 & 15606.5 & 162.7 & 39.4 & 7.1 & 3.6 & 19.2 & 4.1 & 4.6 & 5.7 & 4.9 & 5.7 & 8.4 & 9.2 & 9.3 & 10.0 & 1.7 & 4.8 \\
\hline Kazakhstan & & & 78.8 & 1381.0 & 1662.3 & 1892.0 & 176.3 & 39.1 & 17.4 & 7.1 & 8.3 & 13.2 & 8.4 & 5.9 & 6.4 & 6.9 & 7.6 & 8.6 & 10.8 & 17.2 & 7.3 & 6.9 \\
\hline Kyrgyz Republic & & & 85.0 & 855.0 & 772.4 & 180.7 & 43.5 & 31.9 & 23.4 & 10.5 & 35.9 & 18.7 & 6.9 & 2.0 & 2.5 & 4.0 & 5.2 & 5.7 & 10.2 & 24.5 & 6.8 & 6.4 \\
\hline Moldova & & & & & & & 29.9 & 23.5 & 11.8 & 7.7 & 39.3 & 31.3 & 9.8 & 5.3 & 11.7 & 12.5 & 12.0 & 12.8 & 12.4 & 12.8 & -0.1 & 7.4 \\
\hline Russia & 2.0 & 5.6 & 92.7 & 1526.0 & 875.0 & 311.4 & 197.7 & 47.8 & 14.7 & 27.8 & 85.7 & 20.8 & 21.6 & 16.0 & 13.6 & 11.0 & 12.5 & 9.8 & 9.1 & 14.1 & 11.7 & 6.7 \\
\hline Tajikistan & 2.0 & 5.6 & 111.6 & 1156.7 & 2600.7 & 350.4 & 612.5 & 418.5 & 88.0 & 43.2 & 27.5 & 32.9 & 38.6 & 12.2 & 16.4 & 7.2 & 7.3 & 10.0 & 13.1 & 20.5 & 6.4 & 7.5 \\
\hline Turkmenistan & 2.1 & 4.6 & 103.0 & 493.0 & 3102.0 & 1748.0 & 1005.3 & 992.4 & 83.7 & 16.8 & 24.2 & 8.3 & 11.6 & 8.8 & 5.6 & 5.9 & 10.7 & 8.2 & 6.3 & 14.5 & -2.7 & 5.0 \\
\hline Ukraine & 2.2 & 4.2 & 91.0 & 1210.0 & 4734.0 & 891.0 & 377.0 & 80.0 & 15.9 & 10.6 & 22.7 & 28.2 & 12.0 & 0.8 & 5.2 & 9.0 & 13.5 & 9.1 & 12.8 & 25.2 & 15.9 & 10.8 \\
\hline Uzbekistan & 0.7 & 4.0 & 109.7 & 645.1 & 534.2 & 1568.3 & 304.6 & 54.0 & 70.9 & 29.0 & 29.1 & 25.0 & 27.3 & 27.3 & 11.6 & 6.6 & 10.0 & 14.2 & 12.3 & 12.7 & 14.1 & 10.0 \\
\hline
\end{tabular}

Source: The EBRD, Transition Report (various issues), and the EBRD website (http://www.ebrd.com/what-we-do/economic-research-and-data/data/forecasts-macro-data-transition-indicators.html) 
Table 3. List of selected studies of the effect of central bank independence on inflation and breakdown of collected estimates for meta-analysis

\begin{tabular}{|c|c|c|c|c|c|c|c|c|c|c|c|c|c|c|c|}
\hline \multirow{3}{*}{ Author (Publication year) } & \multicolumn{5}{|c|}{ Target country } & \multirow{3}{*}{$\begin{array}{l}\text { Estimation } \\
\text { period }^{\mathrm{d}}\end{array}$} & \multirow{3}{*}{ Data type } & \multicolumn{6}{|c|}{ CBI variable } & \multirow{3}{*}{$\begin{array}{l}\text { Number of } \\
\text { collected } \\
\text { estimates }\end{array}$} & \multirow{3}{*}{$\begin{array}{c}\text { Average } \\
\text { precision } \\
(A P)^{\mathrm{e}}\end{array}$} \\
\hline & \multirow{2}{*}{$\begin{array}{l}\text { Number of } \\
\text { countries }\end{array}$} & \multicolumn{4}{|c|}{ Breakdown by country group } & & & & & & & & & & \\
\hline & & $\begin{array}{l}\text { CEE EU } \\
\text { countries }^{\text {a }}\end{array}$ & $\begin{array}{c}\text { Other CEE } \\
\text { countries }\end{array}$ & $\begin{array}{c}\text { FSU } \\
\text { countries }\end{array}$ & Others $^{c}$ & & & $\begin{array}{l}\text { nsive } \\
\text { index }\end{array}$ & index & index & index & turnover & term & & \\
\hline Loungani and Sheets (1997) & 12 & 7 & 1 & 4 & 0 & 1993 & Cross & $\checkmark$ & & & & & $\checkmark$ & 7 & 11.24 \\
\hline Maliszewski (2000) & 20 & 8 & 2 & 10 & 0 & 1990-1998 & Cross, Panel & $\checkmark$ & $\checkmark$ & $\checkmark$ & & & & 29 & 113.10 \\
\hline Cukierman et al. (2002) & 26 & 11 & 2 & 12 & 1 & 1989-1998 & Panel & & & & $\checkmark$ & & & 6 & 25.04 \\
\hline Eijffinger and Stadhouders (2003) & 18 & 10 & 1 & 7 & 0 & 1990-1996 & Cross & & & & $\checkmark$ & & & 20 & 2.84 \\
\hline Hammermann and Flanagan (2007) & 19 & 10 & 5 & 4 & 0 & 1995-2004 & Panel & & & & $\checkmark$ & & & 2 & 15.93 \\
\hline Dumiter (2011) & 20 & 8 & 5 & 4 & 3 & 2006-2008 & Panel & $\checkmark$ & & & & & & 2 & 6.05 \\
\hline Maslowska (2011) & 25 & 11 & 2 & 11 & 1 & 1990-2007 & Panel & $\checkmark$ & $\checkmark$ & $\checkmark$ & $\checkmark$ & $\checkmark$ & & 11 & 2.47 \\
\hline Bogoev et al. (2012a) & 17 & 11 & 4 & 2 & 0 & 1990-2009 & Panel & $\checkmark$ & & & $\checkmark$ & & & 8 & 87.33 \\
\hline Bogoev et al. (2012b) & 28 & 11 & 4 & 12 & 1 & $1990-2010$ & Panel & $\checkmark$ & & & $\checkmark$ & & & 16 & 26.46 \\
\hline Petrevski et al. (2012) & 17 & 11 & 4 & 2 & 0 & 1990-2009 & Panel & $\checkmark$ & & & $\checkmark$ & & & 8 & 24.96 \\
\hline
\end{tabular}


(b) Non-transition studies

\begin{tabular}{|c|c|c|c|c|c|c|c|c|c|c|c|c|}
\hline \multirow{3}{*}{ Author (Publication year) } & \multicolumn{3}{|c|}{ Target countries } & \multirow{3}{*}{$\begin{array}{c}\text { Estimation } \\
\text { period }^{\mathrm{d}}\end{array}$} & \multirow{3}{*}{ Data type } & \multicolumn{5}{|c|}{ CBI variable } & \multirow{3}{*}{$\begin{array}{l}\text { Number of } \\
\text { collected } \\
\text { estimates }\end{array}$} & \multirow{3}{*}{$\begin{array}{c}\text { Average } \\
\text { precision } \\
(A P)^{\mathrm{e}}\end{array}$} \\
\hline & \multirow{2}{*}{$\begin{array}{l}\text { Number of } \\
\text { countries }\end{array}$} & \multicolumn{2}{|c|}{ Breakdown by country group } & & & & & & & & & \\
\hline & & Developed countries & Developing countries & & & index & inaex & moex & maex & turnover & & \\
\hline Walsh (1997) & 19 & 19 & 0 & 1980-1993 & Cross & & & & $\checkmark$ & & 2 & 120.69 \\
\hline de Haan and Kooi (2000) & 75 & 0 & 75 & 1980-1989 & Cross & & & & & $\checkmark$ & 17 & 16.62 \\
\hline Sturm and de Haan (2001) & 76 & 0 & 76 & 1990-1989 & Cross & & & & & $\checkmark$ & 4 & 0.09 \\
\hline Eijffinger and Stadhouders (2003) & 44 & 17 & 27 & 1980-1989 & Cross & & & & $\checkmark$ & $\checkmark$ & 31 & 7.01 \\
\hline Gutiérrez (2004) & 25 & 0 & 25 & $1995-2001$ & Cross & & $\checkmark$ & & $\checkmark$ & & 13 & 108.92 \\
\hline Jácome and Vázquez (2005) & 24 & 0 & 24 & 1990-2002 & Panel & $\checkmark$ & & & $\checkmark$ & & 18 & 132.09 \\
\hline Jácome and Vázquez (2008) & 24 & 0 & 24 & 1985-1992 & Panel & $\checkmark$ & & & $\checkmark$ & $\checkmark$ & 18 & 72.61 \\
\hline Krause and Méndez (2008) & 12 & 0 & 12 & 1980-1999 & Panel & & & & & $\checkmark$ & 2 & 5.93 \\
\hline Dumiter (2011) & 20 & 20 & 0 & 2006-2008 & Panel & $\checkmark$ & & & & & 2 & 9.35 \\
\hline Maslowska (2011) & 63 & 0 & 63 & $1980-2007$ & Panel & $\checkmark$ & $\checkmark$ & $\checkmark$ & $\checkmark$ & $\checkmark$ & 41 & 28.44 \\
\hline Perera et al. (2013) & 18 & 6 & 12 & 1996-2008 & Panel & & & & & $\checkmark$ & 21 & 14.10 \\
\hline Alpanda and Honig (2014) & 22 & 22 & 0 & $1980-2006$ & Panel & & & & $\checkmark$ & $\checkmark$ & 4 & 0.13 \\
\hline
\end{tabular}

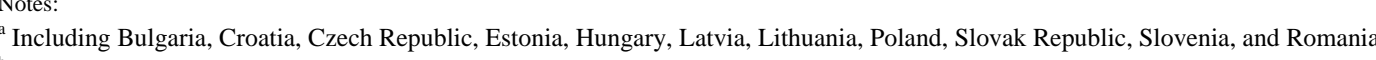

Excluding Baltic countries

Denotes Mongolia and other emerging economies

Estimation period may differ depending on target countries.

${ }^{e} A P$ is defined as the mean of the inverse of the standard errors of estimates collected from the study.

Source: Complied by the authors 
Table 4. Descriptive statistics of the partial correlation coefficients and the $t$ values of collected estimates (a) PCC

\begin{tabular}{|c|c|c|c|c|c|c|c|c|}
\hline & $\begin{array}{c}\text { Number of } \\
\text { collected } \\
\text { estimates }(K) \\
\end{array}$ & Mean & Median & S.D. & Max. & Min. & Kurtosis & Skewness \\
\hline Transition studies & 109 & -0.134 & -0.069 & 0.276 & 0.456 & -0.798 & 0.073 & -0.413 \\
\hline Non-transition studies & 173 & -0.163 & -0.169 & 0.202 & 0.445 & -0.798 & 0.628 & 0.253 \\
\hline
\end{tabular}

(b) $t$ value

\begin{tabular}{lrrrrrrr}
\hline & $\begin{array}{c}\text { Number of } \\
\text { collected } \\
\text { estimates }(K)\end{array}$ & Mean & Median & S.D. & Max. & Min. & Kurtosis \\
\hline Transition studies & 109 & -0.952 & -0.500 & 2.167 & 5.833 & -6.000 & 0.579 \\
Non-transition studies & 173 & -1.665 & -1.933 & 1.920 & 4.510 & -8.057 & 1.178 \\
\hline
\end{tabular}

Note: With regard to the estimates of governor turnover, their signs are reversed to use for meta-analysis.

Source: Author's calculation 

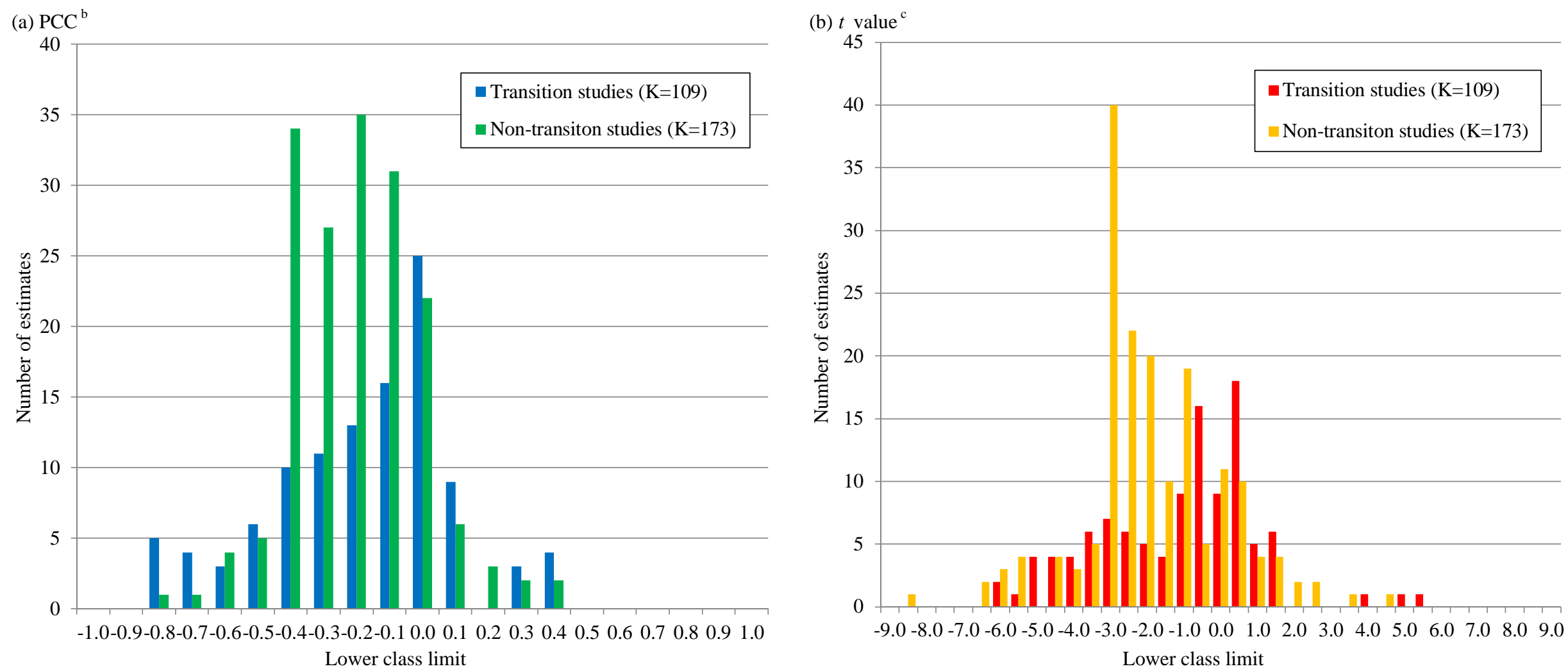

Figure 2. Distribution of partial correlation coefficients and values $^{\mathrm{a}}$

Notes:

${ }^{a}$ With regard to the estimates of governor turnover, their signs are reversed to use for meta-analysis.

${ }^{\mathrm{b}}$ Goodness-of-fit test for transition studies: $\chi^{2}=33.425, p=0.001$; non-transition studies: $\chi^{2}=21.236, p=0.047$

${ }^{\mathrm{c}}$ Goodness-of-fit test for transition studies: $\chi^{2}=49.049, p=0.003$; non-transition studies: $\chi^{2}=98.825, p=0.000$ Source: Authors' illustration 
Table 5. Synthesis of collected estimates

\begin{tabular}{|c|c|c|c|c|c|c|c|c|}
\hline & \multirow{2}{*}{$\begin{array}{c}\text { Number } \\
\text { of } \\
\text { estimates } \\
(K)\end{array}$} & \multicolumn{3}{|c|}{ (a) Synthesis of PCCs } & \multicolumn{4}{|c|}{ (b) Combination of $t$ values } \\
\hline & & $\begin{array}{c}\text { Fixed-effect } \\
\text { model } \\
(z \text { value })^{\mathrm{b}}\end{array}$ & $\begin{array}{c}\text { Random-effects } \\
\text { model } \\
(z \text { value })^{\mathrm{b}}\end{array}$ & $\begin{array}{c}\text { Test of } \\
\text { homogeneity }^{c}\end{array}$ & $\begin{array}{c}\text { Unweighted } \\
\text { combination } \\
(p \text { value })\end{array}$ & $\begin{array}{l}\text { Weighted } \\
\text { combination } \\
(p \text { value })\end{array}$ & $\begin{array}{c}\text { Median of } t \\
\text { values }\end{array}$ & $\begin{array}{c}\text { Fail-safe } \mathrm{N} \\
\left(f_{S N}\right)\end{array}$ \\
\hline Transition studies & 109 & $\begin{array}{l}-0.0588^{* * *} \\
(-7.19)\end{array}$ & $\begin{array}{l}-0.114 \\
(-5.54)\end{array}$ & $554.359^{* * *}$ & $\begin{array}{l}-9.9388^{* * *} \\
(0.00)\end{array}$ & $\begin{array}{l}-1.7799^{* *} \\
(0.04)\end{array}$ & -0.500 & 3870 \\
\hline \multicolumn{9}{|l|}{ Comparison in terms of target country } \\
\hline Studies that use observations, of which the share of CEE EU countries is more than $50 \%$ & 45 & $\begin{array}{l}-0.0988^{* * *} \\
(-6.85)\end{array}$ & $\begin{array}{l}-0.111 \\
(-3.44)\end{array}$ & $152.069^{* * *}$ & $\begin{array}{l}-6.157^{* * *} \\
(0.00)\end{array}$ & $\begin{array}{l}-1.364 \text { * } \\
(0.09)\end{array}$ & -0.500 & 585 \\
\hline Studies that use observations, of which the share of CEE EU countries is less than $50 \%$ & 64 & $\begin{array}{l}-0.039^{* * *} \\
(-4.03)\end{array}$ & $\begin{array}{l}-0.117^{* * *} \\
(-4.43)\end{array}$ & $390.737^{* * *}$ & $\begin{array}{l}-7.807^{\text {*** }} \\
(0.00)\end{array}$ & $\begin{array}{l}-1.253 \\
(0.11)\end{array}$ & -0.500 & 1378 \\
\hline \multicolumn{9}{|l|}{ Comparison in terms of estimation period } \\
\hline Studies in which the estimation period range is within the 1990s & 62 & $\begin{array}{l}-0.154^{* * *} \\
(-8.98)\end{array}$ & $\begin{array}{l}-0.148^{* * *} \\
(-4.14)\end{array}$ & $228.058^{* * *}$ & $\begin{array}{l}-8.004^{* * *} \\
(0.00)\end{array}$ & $\begin{array}{r}-1.143 \\
(0.13)\end{array}$ & -0.829 & 1406 \\
\hline Studies in which the estimation period includes the 2000s & 47 & $\begin{array}{l}-0.031^{* * *} \\
(-3.36)\end{array}$ & $\begin{array}{l}-0.075^{* * *} \\
(-3.08)\end{array}$ & $286.096^{* * *}$ & $\begin{array}{l}-5.942^{* * *} \\
(0.00)\end{array}$ & $\begin{array}{l}-2.150 \text { ** } \\
(0.02)\end{array}$ & -0.270 & 566 \\
\hline \multicolumn{9}{|l|}{ Comparison in terms of data type } \\
\hline Studies that employ cross-sectional data & 43 & $\begin{array}{l}-0.312^{* * *} \\
(-9.14)\end{array}$ & $\begin{array}{l}-0.256^{* * *} \\
(-4.61)\end{array}$ & $106.281^{* * *}$ & $\begin{array}{l}-7.629^{* * *} \\
(0.00)\end{array}$ & $\begin{array}{l}-1.6511^{* *} \\
(0.05)\end{array}$ & -0.857 & 882 \\
\hline Studies that employ panel data & 66 & $\begin{array}{l}-0.043^{* * *} \\
(-5.17)\end{array}$ & $\begin{array}{l}-0.0688^{* * *} \\
(-3.22)\end{array}$ & $389.441^{* * *}$ & $\begin{array}{l}-6.6144^{* * *} \\
(0.00)\end{array}$ & $\begin{array}{r}-1.078 \\
(0.14)\end{array}$ & -0.237 & 1001 \\
\hline \multicolumn{9}{|l|}{ Comparison in terms of CBI variable } \\
\hline Studies that use the comprehensive index & 54 & $\begin{array}{l}-0.061 \\
(-5.67)\end{array}$ & $\begin{array}{l}-0.124 \\
(-3.95)\end{array}$ & $395.558^{* * *}$ & $\begin{array}{l}-8.231 \\
(0.00)\end{array}$ & $\begin{array}{l}-1.281{ }^{*} \\
(0.10)\end{array}$ & -0.652 & 1298 \\
\hline Studies that use the political index & 2 & $\begin{array}{l}-0.395^{* * *} \\
(-3.06)\end{array}$ & $\begin{array}{l}-0.395 \\
(-3.06)\end{array}$ & 0.428 & $\begin{array}{l}-3.069^{* * *} \\
(0.00)\end{array}$ & $\begin{array}{l}-0.538 \\
(0.30)\end{array}$ & -2.170 & 5 \\
\hline Studies that use the economic index & 2 & $\begin{array}{l}-0.4766^{* * *} \\
(-4.01)\end{array}$ & $\begin{array}{l}-0.436 \\
(-1.64)\end{array}$ & $4.829^{* *}$ & $\begin{array}{l}-3.781^{* * *} \\
(0.00)\end{array}$ & $\begin{array}{r}-0.663 \\
(0.25)\end{array}$ & -2.674 & 9 \\
\hline Studies that use the legal index & 47 & $\begin{array}{l}-0.040^{* * *} \\
(-3.21)\end{array}$ & $\begin{array}{l}-0.060 \\
(-2.64)\end{array}$ & $103.462^{* *}$ & $\begin{array}{l}-3.656^{* * *} \\
(0.00)\end{array}$ & $\begin{array}{l}-0.888 \\
(0.19)\end{array}$ & -0.250 & 185 \\
\hline Studies that use governor turnover & 1 & $\begin{array}{l}-0.798^{* * *} \\
(-5.12)\end{array}$ & $\begin{array}{l}-0.798^{* * *} \\
(-5.12)\end{array}$ & 0.000 & $\begin{array}{l}-5.120 \text { *** } \\
(0.00)\end{array}$ & $\begin{array}{l}-5.120 \\
(0.00)\end{array}$ & -5.120 & 9 \\
\hline Studies that use governor term & 3 & $\begin{array}{l}-0.3922^{* *} \\
(-2.31)\end{array}$ & $\begin{array}{l}-0.376^{* *} \\
(-2.02)\end{array}$ & 2.315 & $\begin{array}{l}-1.9644^{* *} \\
(0.02)\end{array}$ & $\begin{array}{c}-0.218 \\
(0.41)\end{array}$ & -0.500 & 1 \\
\hline Non-transition studies & 173 & $\begin{array}{c}-0.114 \\
(-20.29)\end{array}$ & $\begin{array}{c}-0.152^{* * *} \\
(-12.05)\end{array}$ & $695.640^{* * *}$ & $\begin{array}{c}-21.8044^{* * *} \\
(0.00)\end{array}$ & $\begin{array}{l}-3.930 \\
(0.00)\end{array}$ & -1.933 & 30221 \\
\hline
\end{tabular}

Notes:

${ }^{\mathrm{b}}$ Null hypothesis: The synthesized effect size is zero.

' Null hypothesis: Effect sizes are homogeneous.

$* * *$, **, and $*$ denote statistical significance at the $1 \%, 5 \%$, and $10 \%$ levels, respectively.

Source: Authors' estimation 
Table 6. Name, definition, and descriptive statistics of meta-independent variables

\begin{tabular}{|c|c|c|c|c|}
\hline \multirow{2}{*}{ Variable name } & \multirow{2}{*}{ Definition } & \multicolumn{3}{|c|}{ Descriptive statistics $^{a}$} \\
\hline & & Mean & Median & S.D. \\
\hline Proportion of other CEEs & Proportion of non-EU CEE countries in observations & 0.120 & 0.100 & 0.063 \\
\hline Proportion of FSUs & Proportion of FSU countries in observations & 0.382 & 0.429 & 0.128 \\
\hline Proportion of non-CEE/FSU countries & Proportion of Mongolia and other emerging countries in observations & 0.014 & 0.000 & 0.025 \\
\hline First year of estimation & First year of the estimation period & 1991.028 & 1990 & 2.706 \\
\hline Length of estimation & Years of the estimation period & 11.661 & 9 & 6.177 \\
\hline Panel data & $1=$ if panel data is employed for the estimation, $0=$ otherwise & 0.606 & 1 & 0.491 \\
\hline OLS & $1=$ if ordinary least squares estimator is used for the estimation, $0=$ otherwise & 0.468 & 0 & 0.501 \\
\hline Transformed variable & $1=$ if the inflation variable is the transformed value, $0=$ otherwise & 0.817 & 1 & 0.389 \\
\hline Log value & $1=$ if the inflation variable is the $\log$ value, $0=$ otherwise & 0.147 & 0 & 0.356 \\
\hline Ranking value & $1=$ if the inflation variable is the ranking value, $0=$ otherwise & 0.018 & 0 & 0.135 \\
\hline Political index & $1=$ if $\mathrm{CBI}$ is measured by the political index, $0=$ otherwise & 0.018 & 0 & 0.135 \\
\hline Economic index & $1=$ if $\mathrm{CBI}$ is measured by the economic index, $0=$ otherwise & 0.018 & 0 & 0.135 \\
\hline Legal index & $1=$ if $\mathrm{CBI}$ is measured by the legal index, $0=$ otherwise & 0.431 & 0 & 0.498 \\
\hline Governor turnover $^{\mathrm{b}}$ & $1=$ if $\mathrm{CBI}$ is measured by governor turnover, $0=$ otherwise & 0.009 & 0 & 0.096 \\
\hline Governor term & $1=$ if $\mathrm{CBI}$ is measured by the governor term, $0=$ otherwise & 0.028 & 0 & 0.164 \\
\hline Lagged CBI variable & 1 = if a lagged variable of index for central bank independence is used for the estimation, $0=$ otherwise & 0.266 & 0 & 0.444 \\
\hline$\sqrt{ }$ Degree of freedom & Root of the degree of freedom of the estimated model ${ }^{c}$ & 9.902 & 9.434 & 6.126 \\
\hline Quality level & Ten-point scale of the quality level of the study ${ }^{\mathrm{d}}$ & 4.385 & 4 & 3.477 \\
\hline Transition studies & $1=$ transition studies, $0=$ non-transition studies & 0.387 & 0 & 0.000 \\
\hline
\end{tabular}

${ }^{a}$ In case of the variable named "Transition studies," the descriptive statistics of all selected studies are reported. Otherwise, those of the transition studies are reported.

${ }^{\mathrm{b}}$ With regard to the estimates of governor turnover, their signs are reversed to use for meta-analysis.

${ }^{c}$ Descriptive statistics of all selected studies are as follows: mean: 10.944, median: 9.938, S.D.: 6.347.

${ }^{\mathrm{d}}$ See Appendix A for more details. Descriptive statistics of all selected studies are as follows: mean: 4.220, median: 1, S.D.: 3.632.

Source: Authors' calculation 
Table 7. Meta-regression analysis of heterogeneity among studies of transition economies ${ }^{\mathrm{a}}$

(a) Dependent variable-PCC

\begin{tabular}{|c|c|c|c|c|c|c|}
\hline Estimator (analytical weight in parentheses) & $\begin{array}{l}\text { Cluster-robust } \\
\text { OLS }\end{array}$ & $\begin{array}{c}\text { Cluster-robust } \\
\text { WLS } \\
\text { [Quality level] }\end{array}$ & $\begin{array}{c}\text { Cluster-robust } \\
\text { WLS } \\
{[N]}\end{array}$ & $\begin{array}{c}\text { Cluster-robust } \\
\text { WLS } \\
{[1 / S E]}\end{array}$ & $\begin{array}{c}\text { Multilevel } \\
\text { mixed-effects } \\
\text { RML }\end{array}$ & $\begin{array}{c}\text { Random-effects } \\
\text { panel GLS }\end{array}$ \\
\hline Meta-independent variable (default) / Model & [1] & [2] & [3] & {$[4]$} & [5] & {$[6]^{\mathrm{b}}$} \\
\hline \multicolumn{7}{|l|}{$\begin{array}{l}\text { Composition of target countries (CEE EU countries) } \\
\text { (CE }\end{array}$} \\
\hline Proportion of other CEEs & $\begin{array}{l}-9.956 \\
(9.65)\end{array}$ & $\begin{array}{c}-7.469 \\
(10.19)\end{array}$ & $\begin{array}{c}-23.689^{* * *} \\
(6.90)\end{array}$ & $\begin{array}{c}-34.031^{* * *} \\
(4.44)\end{array}$ & $\begin{array}{l}-9.956 \\
(8.81)\end{array}$ & $\begin{array}{r}-9.956 \\
(9.65)\end{array}$ \\
\hline Proportion of FSUs & $\begin{array}{r}-4.232 \\
(2.85)\end{array}$ & $\begin{array}{c}-5.390 * \\
(2.86)\end{array}$ & $\begin{array}{l}-8.3400^{* * *} \\
(2.05)\end{array}$ & $\begin{array}{c}-10.677^{* * *} \\
(1.30)\end{array}$ & $\begin{array}{r}-4.232 \\
(2.61)\end{array}$ & $\begin{array}{r}-4.232 \\
(2.85)\end{array}$ \\
\hline Proportion of non-CEE/FSU countries & $\begin{array}{l}62.7488^{* * *} \\
(15.97)\end{array}$ & $\begin{array}{l}26.767 * \\
(13.97)\end{array}$ & $\begin{array}{l}39.720^{* * *} \\
(11.34)\end{array}$ & $\begin{array}{l}24.433^{* * *} \\
(7.30)\end{array}$ & $\begin{array}{l}62.7488^{* * *} \\
(14.58)\end{array}$ & $\begin{array}{l}62.7488^{* * *} \\
(15.97)\end{array}$ \\
\hline \multicolumn{7}{|l|}{ Estimation period } \\
\hline First year of estimation & $\begin{array}{r}0.323 \\
(0.20)\end{array}$ & $\begin{array}{r}0.076 \\
(0.23)\end{array}$ & $\begin{array}{l}0.6099^{* * *} \\
(0.14)\end{array}$ & $\begin{array}{l}0.864^{* * *} \\
(0.09)\end{array}$ & $\begin{array}{l}0.323^{*} \\
(0.19)\end{array}$ & $\begin{array}{r}0.323 \\
(0.20)\end{array}$ \\
\hline Length of estimation & $\begin{array}{l}0.027 \\
(0.03)\end{array}$ & $\begin{array}{l}-0.040 \\
(0.03)\end{array}$ & $\begin{array}{l}0.059^{* * *} \\
(0.01)\end{array}$ & $\begin{array}{l}0.1011^{* * *} \\
(0.01)\end{array}$ & $\begin{array}{l}0.027 \\
(0.02)\end{array}$ & $\begin{array}{l}0.027 \\
(0.03)\end{array}$ \\
\hline \multicolumn{7}{|l|}{ Data type (cross-sectional data) } \\
\hline Panel data & $\begin{array}{l}-4.214^{* * *} \\
(1.05)\end{array}$ & $\begin{array}{l}-0.484 \\
(0.79)\end{array}$ & $\begin{array}{l}-2.705^{* * *} \\
(0.74)\end{array}$ & $\begin{array}{l}-2.009^{* * *} \\
(0.48)\end{array}$ & $\begin{array}{l}-4.214^{* * *} \\
(0.96)\end{array}$ & $\begin{array}{l}-4.214^{* * *} \\
(1.05)\end{array}$ \\
\hline \multicolumn{7}{|l|}{ Estimator (other than OLS) } \\
\hline OLS & $\begin{array}{l}-4.947^{\text {*** }} \\
(1.50)\end{array}$ & $\begin{array}{l}-0.487 \\
(1.16)\end{array}$ & $\begin{array}{l}-2.784^{* *} \\
(1.03)\end{array}$ & $\begin{array}{l}-1.723^{* *} \\
(0.67)\end{array}$ & $\begin{array}{l}-4.947^{* * *} \\
(1.37)\end{array}$ & $\begin{array}{l}-4.947^{* * *} \\
(1.50)\end{array}$ \\
\hline \multicolumn{7}{|l|}{ Inflation variable type (normal use) } \\
\hline Transformed variable & $\begin{array}{l}7.158^{* * *} \\
(1.63)\end{array}$ & $\begin{array}{l}4.431^{* *} \\
(1.88)\end{array}$ & $\begin{array}{l}9.420^{* * *} \\
(1.08)\end{array}$ & $\begin{array}{l}11.085^{* * *} \\
(0.73)\end{array}$ & $\begin{array}{l}7.1588^{* * *} \\
(1.49)\end{array}$ & $\begin{array}{l}7.158^{* * * *} \\
(1.63)\end{array}$ \\
\hline Log value & $\begin{array}{l}3.006{ }^{*} \\
(1.53)\end{array}$ & $\begin{array}{l}3.225^{*} \\
(1.56)\end{array}$ & $\begin{array}{l}5.156^{* * *} \\
(1.02)\end{array}$ & $\begin{array}{l}6.248^{* * *} \\
(0.69)\end{array}$ & $\begin{array}{l}3.0066^{* *} \\
(1.40)\end{array}$ & $\begin{array}{l}3.006{ }^{* *} \\
(1.53)\end{array}$ \\
\hline Ranking value & $\begin{array}{l}3.141 * \\
(1.56)\end{array}$ & $\begin{array}{l}3.408^{*} \\
(1.58)\end{array}$ & $\begin{array}{l}5.3322^{* * *} \\
(1.04)\end{array}$ & $\begin{array}{l}6.4322^{* * *} \\
(0.69)\end{array}$ & $\begin{array}{l}3.141^{* *} \\
(1.42)\end{array}$ & $\begin{array}{l}3.141^{* *} \\
(1.56)\end{array}$ \\
\hline \multicolumn{7}{|l|}{ CBI variable (comprehensive index) } \\
\hline Political index & $\begin{array}{l}-0.011 \\
(0.07)\end{array}$ & $\begin{array}{l}-0.057^{* *} \\
(0.02)\end{array}$ & $\begin{array}{l}-0.071^{* * *} \\
(0.01)\end{array}$ & $\begin{array}{l}-0.038^{* * *} \\
(0.00)\end{array}$ & $\begin{array}{l}-0.011 \\
(0.07)\end{array}$ & $\begin{array}{l}-0.011 \\
(0.07)\end{array}$ \\
\hline Economic index & $\begin{array}{r}-0.038 \\
(0.12)\end{array}$ & $\begin{array}{l}0.057 \\
(0.08)\end{array}$ & $\begin{array}{l}-0.079 \\
(0.15)\end{array}$ & $\begin{array}{l}0.110^{* * *} \\
(0.01)\end{array}$ & $\begin{array}{r}-0.038 \\
(0.11)\end{array}$ & $\begin{array}{l}-0.038 \\
(0.12)\end{array}$ \\
\hline Legal index & $\begin{array}{l}0.014 \\
(0.02)\end{array}$ & $\begin{array}{l}0.012 \\
(0.02)\end{array}$ & $\begin{array}{l}0.015 \\
(0.01)\end{array}$ & $\begin{array}{l}0.012 \\
(0.02)\end{array}$ & $\begin{array}{l}0.014 \\
(0.02)\end{array}$ & $\begin{array}{l}0.014 \\
(0.02)\end{array}$ \\
\hline Governor turnover & $\begin{array}{l}-0.384^{* * *} \\
(0.02)\end{array}$ & $\begin{array}{l}-0.387^{* * *} \\
(0.01)\end{array}$ & $\begin{array}{l}-0.3677^{* * *} \\
(0.03)\end{array}$ & $\begin{array}{l}-0.2311^{* * *} \\
(0.02)\end{array}$ & $\begin{array}{l}-0.384^{* * *} \\
(0.02)\end{array}$ & $\begin{array}{l}-0.384^{* * *} \\
(0.02)\end{array}$ \\
\hline Governor term & $\begin{array}{l}0.3488^{* * *} \\
(0.01)\end{array}$ & $\begin{array}{l}0.357^{* * *} \\
(0.01)\end{array}$ & $\begin{array}{l}0.3566^{* * *} \\
(0.00)\end{array}$ & $\begin{array}{l}0.506 \\
(0.00)\end{array}$ & $\begin{array}{l}0.3488^{* * *} \\
(0.01)\end{array}$ & $\begin{array}{l}0.3488^{* * *} \\
(0.01)\end{array}$ \\
\hline Lagged CBI variable (non-lagged variable) & $\begin{array}{l}-1.4433^{*} \\
(0.74)\end{array}$ & $\begin{array}{l}0.746 \\
(0.58)\end{array}$ & $\begin{array}{l}-0.366 \\
(0.51)\end{array}$ & $\begin{array}{r}-0.075 \\
(0.33)\end{array}$ & $\begin{array}{l}-1.443^{* *} \\
(0.68)\end{array}$ & $\begin{array}{l}-1.443^{*} \\
(0.74)\end{array}$ \\
\hline \multicolumn{7}{|l|}{ Degree of freedom and research quality } \\
\hline$\sqrt{\text { Degree of freedom }}$ & $\begin{array}{c}-0.138 \\
(0.10)\end{array}$ & $\begin{array}{r}0.030 \\
(0.09)\end{array}$ & $\begin{array}{l}0.006 \\
(0.07)\end{array}$ & $\begin{array}{l}0.087^{*} \\
(0.04)\end{array}$ & $\begin{array}{r}-0.138 \\
(0.09)\end{array}$ & $\begin{array}{l}-0.138 \\
(0.10)\end{array}$ \\
\hline Quality level & $\begin{array}{l}0.326^{* * *} \\
(0.03)\end{array}$ & & $\begin{array}{l}0.289 \\
(0.02)\end{array}$ & $\begin{array}{l}0.318 \\
(0.01)\end{array}$ & $\begin{array}{l}0.326 \\
(0.02)\end{array}$ & $\begin{array}{l}0.326^{* * *} \\
(0.03)\end{array}$ \\
\hline Intercept & $\begin{array}{r}-642.934 \\
(409.66) \\
\end{array}$ & $\begin{array}{r}-153.031 \\
(452.55) \\
\end{array}$ & $\begin{array}{c}-1215.514 \\
(280.05) \\
\end{array}$ & $\begin{array}{c}-1724.9688^{* * *} \\
(187.35) \\
\end{array}$ & $\begin{array}{l}-642.934 \text { * } \\
(373.97) \\
\end{array}$ & $\begin{array}{r}-642.934 \\
(409.66) \\
\end{array}$ \\
\hline $\bar{K}$ & 109 & 109 & 109 & 109 & 109 & 109 \\
\hline$R^{2}$ & 0.519 & 0.401 & 0.553 & 0.190 & - & 0.519 \\
\hline
\end{tabular}


(b) Dependent variable $-t$ value

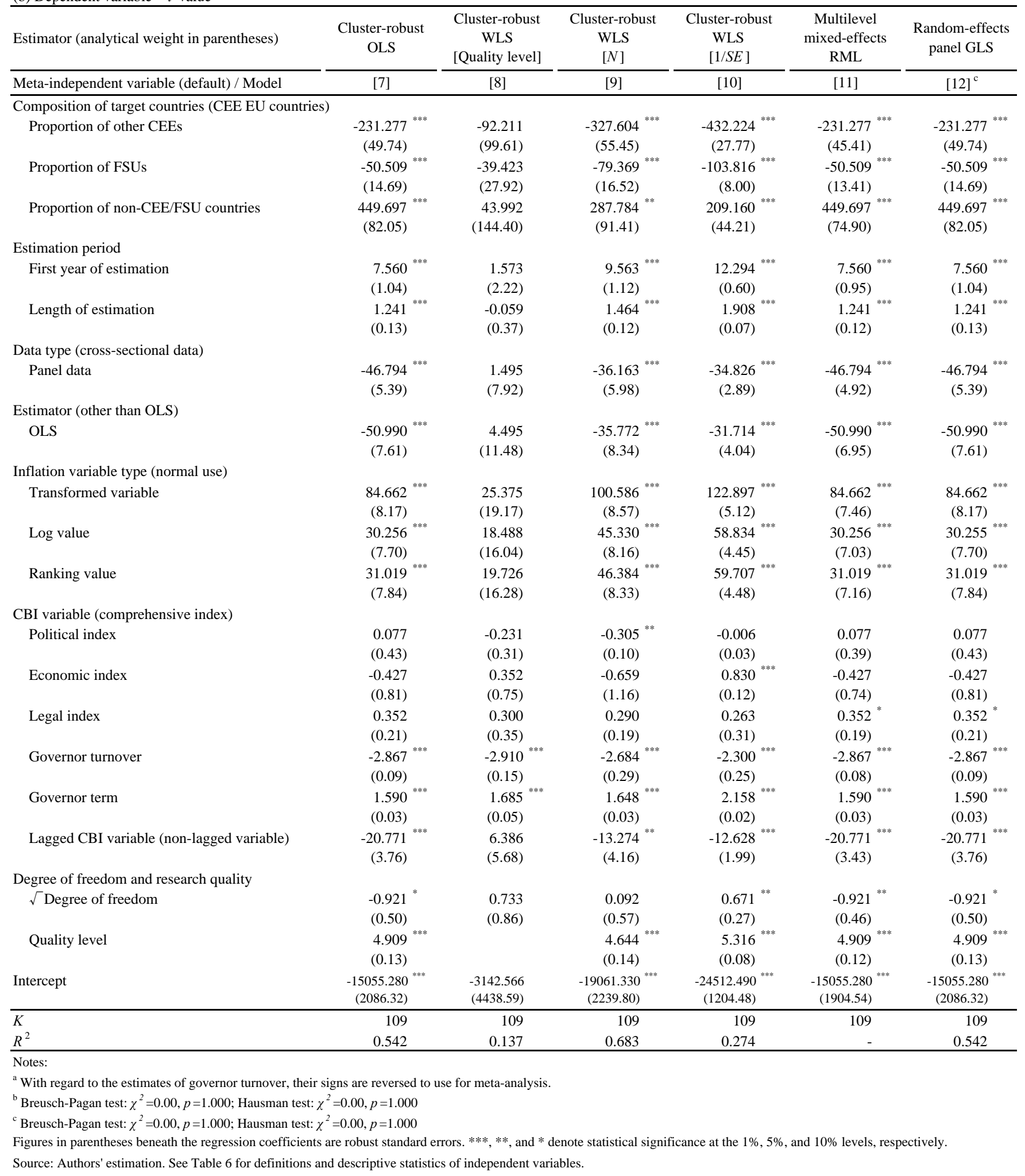


Table 8. Meta-regression analysis of the relative robustness of the disinflation effect of central bank independence in transition economies

(a) Dependent variable-PCC

\begin{tabular}{|c|c|c|c|c|c|c|}
\hline Estimator (analytical weight in parentheses) & $\begin{array}{l}\text { Cluster-robust } \\
\text { OLS }\end{array}$ & $\begin{array}{c}\text { Cluster-robust } \\
\text { WLS } \\
\text { [Quality level] }\end{array}$ & $\begin{array}{c}\text { Cluster-robust } \\
\text { WLS } \\
{[N]}\end{array}$ & $\begin{array}{c}\text { Cluster-robust } \\
\text { WLS } \\
{[1 / S E]}\end{array}$ & $\begin{array}{c}\text { Multilevel } \\
\text { mixed-effects } \\
\text { RML }\end{array}$ & $\begin{array}{c}\text { Random-effects } \\
\text { panel GLS }\end{array}$ \\
\hline Meta-independent variable (default) / Model & [1] & [2] & [3] & {$[4]$} & [5] & {$[6]^{\mathrm{b}}$} \\
\hline \multicolumn{7}{|l|}{ Study type (non-transition studies) } \\
\hline Transition studies & $\begin{array}{l}0.047 \\
(0.06)\end{array}$ & $\begin{array}{r}0.026 \\
(0.05)\end{array}$ & $\begin{array}{l}0.075^{* *} \\
(0.03)\end{array}$ & $\begin{array}{r}0.009 \\
(0.04)\end{array}$ & $\begin{array}{l}0.085 \\
(0.10)\end{array}$ & $\begin{array}{r}0.091 \\
(0.11)\end{array}$ \\
\hline \multicolumn{7}{|l|}{ Degree of freedom and research quality } \\
\hline$\sqrt{\text { Degree of freedom }}$ & $\begin{array}{l}0.009^{* * *} \\
(0.00)\end{array}$ & $\begin{array}{l}0.014^{* *} \\
(0.01)\end{array}$ & $\begin{array}{l}0.006^{* * *} \\
(0.00)\end{array}$ & $\begin{array}{l}0.007^{* *} \\
(0.00)\end{array}$ & $\begin{array}{l}0.015^{* * *} \\
(0.00)\end{array}$ & $\begin{array}{l}0.015^{* * *} \\
(0.00)\end{array}$ \\
\hline Quality level & $\begin{array}{r}-0.007 \\
(0.01)\end{array}$ & & $\begin{array}{r}-0.006 \\
(0.00)\end{array}$ & $\begin{array}{l}-0.003 \\
(0.00)\end{array}$ & $\begin{array}{r}-0.009 \\
(0.01)\end{array}$ & $\begin{array}{l}-0.009 \\
(0.01)\end{array}$ \\
\hline Intercept & $\begin{array}{l}-0.2400^{* * *} \\
(0.06)\end{array}$ & $\begin{array}{l}-0.332^{* * *} \\
(0.07)\end{array}$ & $\begin{array}{l}-0.207^{* * *} \\
(0.04)\end{array}$ & $\begin{array}{l}-0.233^{* * *} \\
(0.05)\end{array}$ & $\begin{array}{l}-0.292^{* * *} \\
(0.09)\end{array}$ & $\begin{array}{l}-0.298^{* * *} \\
(0.09)\end{array}$ \\
\hline $\bar{K}$ & 282 & 282 & 282 & 282 & 282 & 282 \\
\hline$R^{2}$ & 0.092 & 0.086 & 0.144 & 0.053 & - & 0.091 \\
\hline
\end{tabular}

(b) Dependent variable $-t$ value

\begin{tabular}{|c|c|c|c|c|c|c|}
\hline Estimator (analytical weight in parentheses) & $\begin{array}{l}\text { Cluster-robust } \\
\text { OLS }\end{array}$ & $\begin{array}{c}\text { Cluster-robust } \\
\text { WLS } \\
\text { [Quality level] }\end{array}$ & $\begin{array}{c}\text { Cluster-robust } \\
\text { WLS } \\
{[N]}\end{array}$ & $\begin{array}{c}\text { Cluster-robust } \\
\text { WLS } \\
{[1 / S E]}\end{array}$ & $\begin{array}{l}\text { Multilevel } \\
\text { mixed-effects } \\
\text { RML }\end{array}$ & $\begin{array}{c}\text { Random-effects } \\
\text { panel GLS }\end{array}$ \\
\hline Meta-independent variable (default) / Model & [7] & [8] & [9] & [10] & [11] & {$[12]^{\mathrm{c}}$} \\
\hline \multicolumn{7}{|l|}{ Study type (non-transition studies) } \\
\hline Transition studies & $\begin{array}{l}0.732 \\
(0.45)\end{array}$ & $\begin{array}{l}0.527 \\
(0.47)\end{array}$ & $\begin{array}{l}1.1966^{* *} \\
(0.54)\end{array}$ & $\begin{array}{l}0.079 \\
(0.64)\end{array}$ & $\begin{array}{c}0.873 \\
(0.61)\end{array}$ & $\begin{array}{r}0.909 \\
(0.63)\end{array}$ \\
\hline \multicolumn{7}{|l|}{ Degree of freedom and research quality } \\
\hline$\sqrt{ }$ Degree of freedom & $\begin{array}{r}0.002 \\
(0.03)\end{array}$ & $\begin{array}{r}0.003 \\
(0.04)\end{array}$ & $\begin{array}{r}-0.002 \\
(0.02)\end{array}$ & $\begin{array}{l}-0.037 \\
(0.04)\end{array}$ & $\begin{array}{r}0.028 \\
(0.04)\end{array}$ & $\begin{array}{r}0.029 \\
(0.04)\end{array}$ \\
\hline Quality level & $\begin{array}{l}-0.082 \\
(0.05)\end{array}$ & & $\begin{array}{l}-0.101 \\
(0.06)\end{array}$ & $\begin{array}{l}-0.042 \\
(0.07)\end{array}$ & $\begin{array}{l}-0.110 \\
(0.09)\end{array}$ & $\begin{array}{l}-0.110 \\
(0.10)\end{array}$ \\
\hline Intercept & $\begin{array}{l}-1.346^{* *} \\
(0.50)\end{array}$ & $\begin{array}{l}-1.872^{* * *} \\
(0.58)\end{array}$ & $\begin{array}{l}-1.368{ }^{* *} \\
(0.52)\end{array}$ & $\begin{array}{r}-1.183 \\
(0.72) \\
\end{array}$ & $\begin{array}{r}-1.259 \\
(0.87) \\
\end{array}$ & $\begin{array}{r}-1.283 \\
(0.91) \\
\end{array}$ \\
\hline$K$ & 282 & 282 & 282 & 282 & 282 & 282 \\
\hline$R^{2}$ & 0.050 & 0.017 & 0.090 & 0.011 & - & 0.046 \\
\hline
\end{tabular}

${ }^{a}$ With regard to the estimates of governor turnover, their signs are reversed to use for meta-analysis.

${ }^{\mathrm{b}}$ Breusch-Pagan test: $\chi^{2}=17.51, p=0.000$; Hausman test: $\chi^{2}=3.43, p=0.179$

${ }^{\mathrm{c}}$ Breusch-Pagan test: $\chi^{2}=20.51, \mathrm{p}=0.000$; Hausman test: $\chi^{2}=0.62, p=0.735$

Figures in parentheses beneath the regression coefficients are robust standard errors. ${ }^{* * *}$, **, and $*$ denote statistical significance at the $1 \%$, $5 \%$, and $10 \%$ levels, respectively.

Source: Authors' estimation. See Table 6 for definitions and descriptive statistics of independent variables. 
(a) Transition studies $(K=109)$

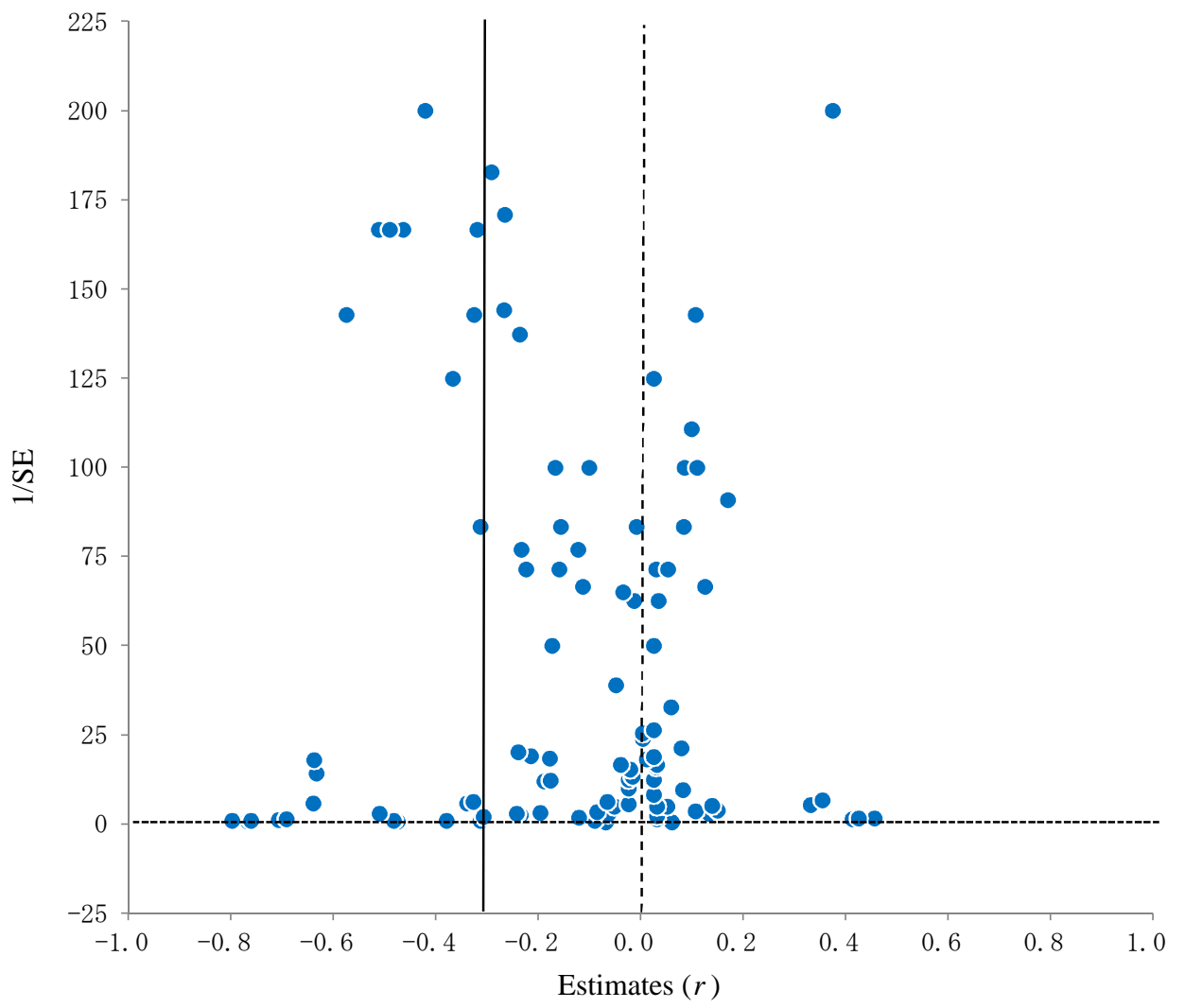

(b) Non-transition studies $(K=173)$

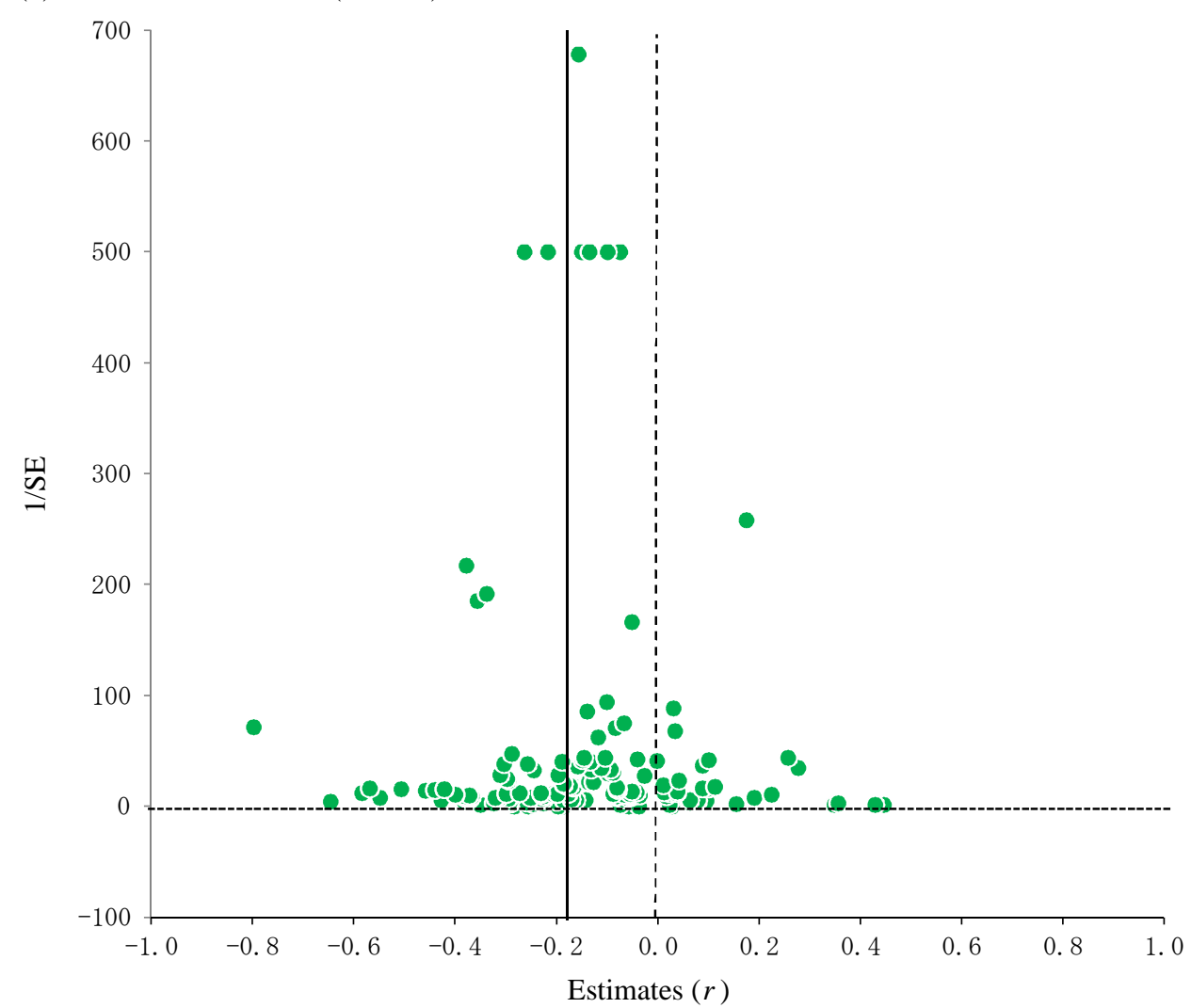

Figure 3. Funnel plot of partial correlation coefficients ${ }^{a}$

Notes:

${ }^{\text {a }}$ With regard to the estimates of governor turnover, their signs are reversed to use for meta-analysis.

Solid line indicates the mean of the top 10 percent most-precise estimates: -0.310 for transition studies; -0.184 for non-transition studies.

Source: Authors' illustration 

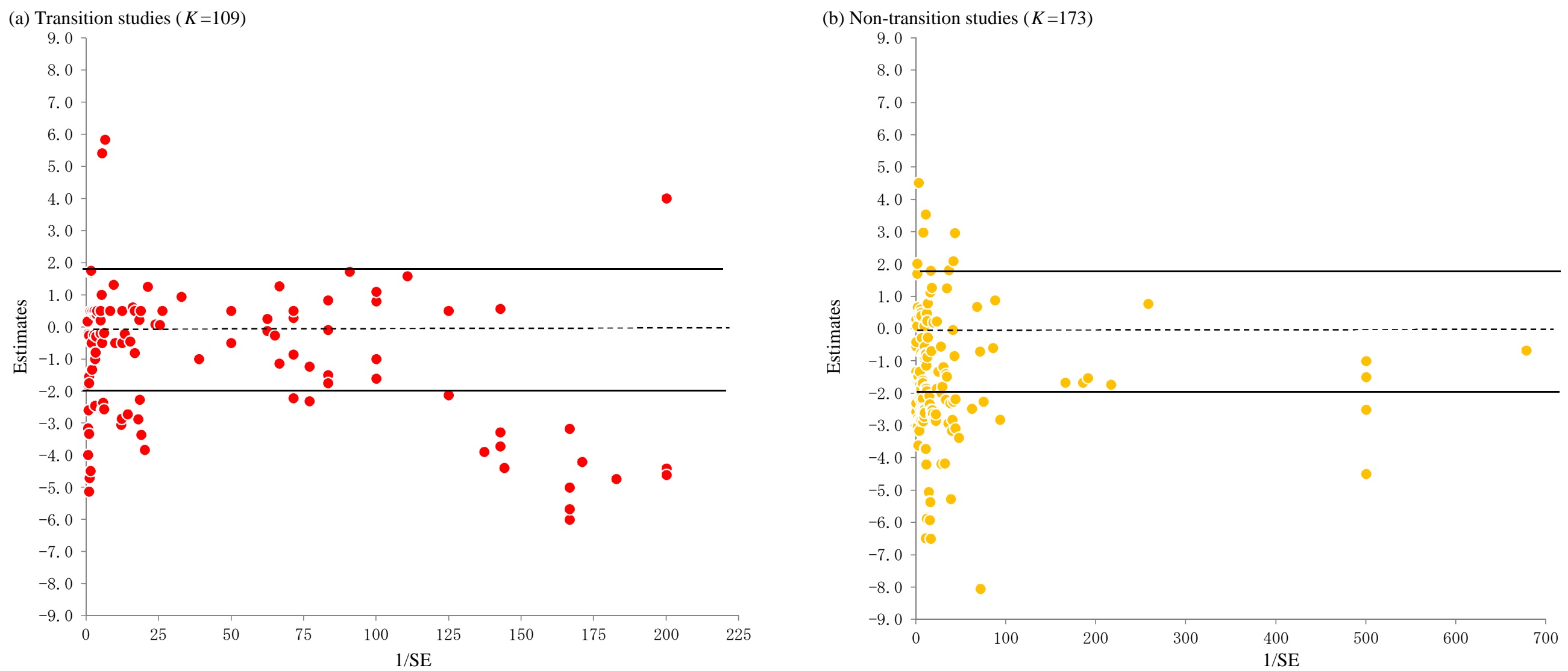

Figure 4. Galbraith plot of $t$ values ${ }^{\mathrm{a}}$

Notes:

${ }^{\mathrm{a}}$ With regard to the estimates of governor turnover, their signs are reversed to use for meta-analysis.

Solid lines indicate the thresholds of two-sided critical values at the $5 \%$ significance level \pm 1.96 .

Source: Authors' illustration 
Table 9. Meta-regression analysis of publication selection ${ }^{\mathrm{a}}$

(a) FAT (type I publication selection bias)-PET test (Equation: $t=\beta_{0}+\beta_{1}(1 / S E)+v$ )

\begin{tabular}{|c|c|c|c|c|c|c|}
\hline \multirow{2}{*}{$\begin{array}{l}\text { Study type } \\
\text { Estimator }\end{array}$} & \multicolumn{3}{|c|}{ Transition studies } & \multicolumn{3}{|c|}{ Non-transition studies } \\
\hline & OLS & $\begin{array}{c}\text { Cluster-robust } \\
\text { OLS }\end{array}$ & $\begin{array}{c}\text { Random- } \\
\text { effects panel } \\
\text { GLS }\end{array}$ & OLS & $\begin{array}{c}\text { Cluster-robust } \\
\text { OLS }\end{array}$ & $\begin{array}{c}\text { Random- } \\
\text { effects panel } \\
\text { GLS }\end{array}$ \\
\hline Model & [1] & [2] & {$[3]^{\mathrm{b}}$} & {$[4]$} & {$[5]$} & {$[6]^{c}$} \\
\hline \multirow{2}{*}{ Intercept (FAT: $\mathrm{H}_{0}: \beta_{0}=0$ ) } & -0.422 & -0.422 & -0.257 & -1.630 & -1.630 & -1.215 \\
\hline & $(0.26)$ & $(0.50)$ & $(0.77)$ & $(0.16)$ & $(0.24)$ & $(0.39)$ \\
\hline \multirow[t]{2}{*}{ 1/SE (PET: $\mathrm{H}_{0}: \beta_{1}=0$ ) } & $-0.012^{* *}$ & $-0.012^{* *}$ & $-0.012^{*}$ & -0.001 & -0.001 & $-0.002^{* * *}$ \\
\hline & $(0.005)$ & $(0.004)$ & $(0.01)$ & $(0.001)$ & $(0.001)$ & $(0.001)$ \\
\hline$K$ & 109 & 109 & 109 & 173 & 173 & 173 \\
\hline$R^{2}$ & 0.095 & 0.095 & 0.095 & 0.001 & 0.001 & 0.001 \\
\hline
\end{tabular}

(b) Test of type II publication selection bias (Equation: $|t|=\beta_{0}+\beta_{1}(1 / S E)+v$ )

\begin{tabular}{|c|c|c|c|c|c|c|}
\hline Study type & & Transition studie & & & n-transition stud & \\
\hline Estimator & OLS & $\begin{array}{c}\text { Cluster-robust } \\
\text { OLS }\end{array}$ & $\begin{array}{c}\text { Random- } \\
\text { effects panel } \\
\text { GLS }\end{array}$ & OLS & $\begin{array}{c}\text { Cluster-robust } \\
\text { OLS }\end{array}$ & $\begin{array}{c}\text { Random- } \\
\text { effects panel } \\
\text { GLS }\end{array}$ \\
\hline Model & [7] & {$[8]$} & {$[9]^{\mathrm{d}}$} & {$[10]$} & [11] & {$[12]^{\mathrm{e}}$} \\
\hline Intercept $\left(\mathrm{H}_{0}: \beta_{0}=0\right)$ & $\begin{array}{l}1.235^{* * *} \\
(0.18)\end{array}$ & $\begin{array}{l}1.235^{* *} \\
(0.38)\end{array}$ & $\begin{array}{l}1.584 \\
(0.59)\end{array}$ & $\begin{array}{l}2.122 \\
(0.11)\end{array}$ & $\begin{array}{l}2.122 \\
(0.18)\end{array}$ & $\begin{array}{l}1.997 \\
(0.20)\end{array}$ \\
\hline $1 / S E$ & $\begin{array}{l}0.011^{* * * *} \\
(0.002)\end{array}$ & $\begin{array}{l}0.011^{* * *} \\
(0.003)\end{array}$ & $\begin{array}{l}0.015^{*} \\
(0.01)\end{array}$ & $\begin{array}{r}-0.0002 \\
(0.001) \\
\end{array}$ & $\begin{array}{r}-0.0002 \\
(0.001) \\
\end{array}$ & $\begin{array}{r}0.0003 \\
(0.001) \\
\end{array}$ \\
\hline$K$ & 109 & 109 & 109 & 173 & 173 & 173 \\
\hline$R^{2}$ & 0.171 & 0.171 & 0.171 & 0.0002 & 0.0002 & 0.0002 \\
\hline
\end{tabular}

(c) PEESE approach (Equation: $t=\beta_{0} S E+\beta_{1}(1 / S E)+v$ )

\begin{tabular}{|c|c|c|c|c|c|c|}
\hline Study type & & Transition studie & & & n-transition stud & \\
\hline Estimator & OLS & $\begin{array}{c}\text { Cluster-robust } \\
\text { OLS }\end{array}$ & $\begin{array}{c}\text { Random- } \\
\text { effects panel } \\
\text { ML }\end{array}$ & OLS & $\begin{array}{c}\text { Cluster-robust } \\
\text { OLS }\end{array}$ & $\begin{array}{c}\text { Random- } \\
\text { effects panel } \\
\text { ML }\end{array}$ \\
\hline Model & [13] & [14] & {$[15]$} & {$[16]$} & [17] & [18] \\
\hline$S E$ & $\begin{array}{l}-1.327^{* * *} \\
(0.40)\end{array}$ & $\begin{array}{l}-1.327^{* * * *} \\
(0.40)\end{array}$ & $\begin{array}{l}-0.183 \\
(0.61)\end{array}$ & $\begin{array}{l}-0.129^{* * *} \\
(0.04)\end{array}$ & $\begin{array}{l}-0.129^{*} \\
(0.06)\end{array}$ & $\begin{array}{l}-0.080 \\
(0.11)\end{array}$ \\
\hline $1 / S E\left(\mathrm{H}_{0}: \beta_{1}=0\right)$ & $\begin{array}{l}-0.015^{* * *} \\
(0.004)\end{array}$ & $\begin{array}{l}-0.015^{* * *} \\
(0.003)\end{array}$ & $\begin{array}{l}-0.012^{* * *} \\
(0.00)\end{array}$ & $\begin{array}{l}-0.006 \\
(0.001) \\
\end{array}$ & $\begin{array}{l}-0.006 \\
(0.001)\end{array}$ & $\begin{array}{l}-0.002 \\
(0.00)\end{array}$ \\
\hline$K$ & 109 & 109 & 109 & 173 & 173 & 173 \\
\hline$R^{2}$ & 0.297 & 0.297 & - & 0.086 & 0.086 & - \\
\hline
\end{tabular}

\section{Notes:}

${ }^{\mathrm{a}}$ With regard to the estimates of governor turnover, their signs are reversed to use for meta-analysis.

${ }^{\mathrm{b}}$ Breusch-Pagan test: $\chi^{2}=19.99, p=0.000$; Hausman test: $\chi^{2}=0.28, p=0.595$

${ }^{\mathrm{c}}$ Breusch-Pagan test: $\chi^{2}=7.29, p=0.003$; Hausman test: $\chi^{2}=0.06, p=0.811$

${ }^{\mathrm{d}}$ Breusch-Pagan test: $\chi^{2}=19.99, p=0.000$; Hausman test: $\chi^{2}=0.28, p=0.595$

${ }^{\mathrm{e}}$ Breusch-Pagan test: $\chi^{2}=7.94, p=0.002$; Hausman test: $\chi^{2}=0.58, p=0.445$

Figures in parentheses beneath the regression coefficients are standard errors. Except for Models [15] and [18], robust standard errors are estimated. ***, $* *$, and $*$ denote statistical significance at the $1 \%, 5 \%$, and $10 \%$ levels, respectively.

Source: Authors' estimation 